\title{
Technologies for the identification and validation of protein-protein interactions
}

\author{
Karoline Pichlerova and Jozef Hanes® \\ Institute of Neuroimmunology, Slovak Academy of Sciences, Bratislava, Slovakia
}

\begin{abstract}
Proteins are large molecules that play essential roles in all living organisms. In most molecular processes in each cell, proteins usually do not function alone but through physiological interactions with various ligands. The most common interacting molecules for proteins are other proteins, and they act together by protein-protein interactions (PPIs) to create larger protein complexes. The impairment of physiological PPIs or establishing PPIs with pathological proteins often leads to the development of diseases. To bring insights on the knowledge about the physiological functions of proteins in biological processes, and to understand the development and pathogenesis of diseases, numerous qualitative and quantitative methods have been developed. In this review, we summarize the most commonly used methods for studying PPIs, and discuss their advantages and drawbacks.
\end{abstract}

Key words: Protein-protein interactions - In vivo methods - In vitro methods - In silico methods

\section{Introduction}

Proteins are essential macromolecules expressed in all living organisms. They fulfill numerous roles in various processes, such as development, gene expression, cell growth and coordination, cell to cell interaction, movement, apoptosis, metabolic processes, the immune response, transportation and storage, cellular defense, and many more. They can act as structural units, muscle contractors, catalysts of biochemical reactions, transporters, storage units, coordinators of functions, cell signal transducers, ligand binders, etc. (Lodish et al. 2021). Depending on the type of process, proteins interact with different ligands, like other proteins, nucleic acids, carbohydrates, lipids, fatty acids, peptides, metabolites, neurotransmitters, and other molecules. Most processes in living organisms are managed by the protein-protein interactions (PPIs) among two or more proteins, whereby they create complexes. Based on the knowledge of PPIs, their interaction networks can be established, helping us to better understand

Correspondence to: Jozef Hanes, Institute of Neuroimmunology, Slovak Academy of Sciences, Dubravska cesta 9, 84510 Bratislava, Slovakia

E-mail: jozef.hanes@savba.sk the physiological processes in the cells (Gonzalez and Kann 2012). The disruption or impairment of physiological PPIs could result in malfunctional, pathological conditions that often cause illnesses, for example, the loss of an interaction between the Von Hippel-Lindau protein, a tumor suppressor protein, with the hypoxia-inducible factor, a transcription factor in the von Hippel-Lindau disease (Ohh et al. 2000). The loss of essential PPIs (Ohh et al. 2000) or interactions of a protein with aberrant ones (for example VDAC1 protein with phosphorylated tau) (Manczak and Reddy 2012) are known in many diseases. Studying the conditions of physiological PPIs and their networks can contribute to our knowledge about the role of specific proteins in the cell. On the other hand, knowledge on the changes in PPIs and their networks in disease stages will help us better understand the pathological changes, and find new possible treatments and/or biological markers for diseases. Up-to-date seven PPI modulators have been approved for clinical use, and drugs against at least 7 additional protein targets are in clinical development to treat various diseases ( $\mathrm{Lu}$ et al. 2020). The accepted drugs with protein targets are a Bcl-2 selective inhibitor (Venetoclax) (Korycka-Wolowiec et al. 2019), used in chronic lympohoblastic leukemia, a CCR5 inhibitor (Maraviroc) (Dorr et al. 2005), which blocks the interaction

(c) The Authors 2021. This is an open access article under the terms of the Creative Commons Attribution-NonCommercial 4.0 International License (https://creativecommons.org/licenses/by-nc/4.0/), which permits non-commercial use, distribution, and reproduction in any medium, provided the original work is properly cited. 
between CCR5 and gp120 used in HIV therapy and a PD-1 inhibitor (Keytruda) (Reck et al. 2016), Opdivo (Borghaei et al. 2015), Tecentriq (Socinski et al. 2018), Bavencio (Boyerinas et al. 2015), Imfinzi (Antonia et al. 2017)), which inhibits the interaction of PD-1 with PD-1L and PD-2L, approved for the use in metastatic/unresectable melanoma, non-small lung cancer and Merkel cell carcinoma.

PPIs were first discovered in the late 19th century by two independent groups as an antibody-antigen interactions. Von Behring and Kitasato studied the animal response to bacterial diphteria and tetanus toxins (von Behring and Kitasato 1991). The second study discovered PPI that originated from animals' immunization experiments with plant toxins: ricin and abrin, and their physiological responses on intoxication (Ehrlich 1891a, 1891b). In the 1930s, Krebs described PPIs in the urea cycle (Krebs and Henseleit 1932), citric acid cycle (Krebs and Johnson 1937), and in the 1950s, the glyoxylate cycle (Kornberg and Krebs 1957). In the 1940s, the phosphorylation of glycogen phosphorylase (PYG) was studied, where the conversion of the active form (PYG-a) to the inactive state (PYG-b) was observed, with the identification of AMP as a prosthetic group (Cori and Cori 1945). Subsequently, in the 1950s, the study of PYG continued with the discovery of ATP as the activational prosthetic group, which resulted in PYG being the first example of an enzyme regulated by phosphorylation (Krebs and Fischer 1962).

In the 1960s, the first methods for studying PPIs were specifically developed. They include starch gel electrophoresis, gel filtration, equilibrium ultracentrifugation and ultracentrifugation in sucrose density gradients (Gally and Edelman 1964). In the 1970s, Förster resonance energy transfer (Huang et al. 1975) and crosslinking technology (Bickle et al. 1972) were established, and used for the study of the topography of the bacterial S30 ribosomal complex (Huang et al. 1975). In the same decade the 2D electrophoresis emerged, which enabled the analysis of proteins in complex mixtures (O'Farrell 1975). In the 1980s, several new methods were developed which significantly advanced the PPI research, namely, surface plasmon resonance (SPR) (Liedberg et al. 1983), phage display (Smith 1985), yeast two-hybrid system (Y2H) (Fields and Song 1989), and mass spectrometry techniques, like, e.g., matrix-assisted laser desorption/ionization (MALDI) (Karas and Hillenkamp 1988; Hillenkamp et al. 1991) and electrospray ionization (ESI) (Fenn et al. 1989).

The development of DNA sequencing methods also supported the identification of novel proteins and PPIs. The first sequencing of a bacteriophage genome was carried out in the year 1977 (Sanger et al. 1977). In the year 1995, the first complete genome of a bacteria ( $H$. influenzae) was sequenced (Fleischmann et al. 1995), and since then, genomes of different organisms have been sequenced, including the genome of $H$. sapiens (Collins et al. 2003). These efforts have revealed thousands of novel genes and proteins, whereby the functions of many of them are yet unknown and have to be discovered. Although many novel proteomic methods and their combinations have been established and adapted for PPIs study, only a small fraction of the overall PPIs have been investigated. Because most of all biological processes are mediated by PPIs, their detailed understanding is one of the major goals of modern biochemistry.

\section{Methods for PPIs studying}

The methods for studying PPIs can be divided into three groups: a) in vivo, b) in vitro, and c) in silico methods. In vivo methods are based on experimenting on living organisms themselves, using various cellular models. In vitro methods are performed entirely in an environment outside of living organisms often using purified proteins. In silico methods are realized by computer simulations. The methods can be further divided as qualitative and quantitative. Methods used for the qualitative study of PPIs can prove that interaction between two or more proteins occurs. They include methods used to identify PPIs by libraries screening, validation of potential PPIs, structural characterization of PPI interfaces, including identifying binding sites of PPIs, interface size, complementarity between surfaces, and conformational changes upon complex formation. Determination of affinity of the interaction, the kinetics of the binding, thermodynamics, stoichiometry, topology, hydrophobicity, stability of the interaction belong to the quantitative properties measured by several methods (Bongrand 1999). The most popular qualitative and quantitative methods for studying PPIs are presented and discussed below, and summarized in Table 1 and 2.

\section{In vivo methods}

The in vivo methods are carried out using living organisms, cell lines, and other single-cell models. Methods in this group mostly describe the interactions qualitatively, although some can be used to study certain quantitative properties. Although they apply to small-scale screenings, several of the methods were also adjusted to high-throughput scales. The models used for PPI studies are Escherichia coli (Joung et al. 2000), Saccharomyces cerevisiae (Fields and Song 1989) or mammalian cell lines like HeLa, COS7 (Suchanek et al. 2005), Jurkat cell lines (Klockenbusch and Kast 2010) or murine cell lines (Vasilescu et al. 2004), Candida albicans (Stynen et al. 2010), rats (Sinsky et al. 2020), mice (Gonzalez-Lozano et al. 2020), neurons from Aplysia californica (Choi et al. 2003), protoplasts from Arabidopsis thaliana (Ehlert et al. 2006), and various cellular models (Embree et al. 2009). The most 


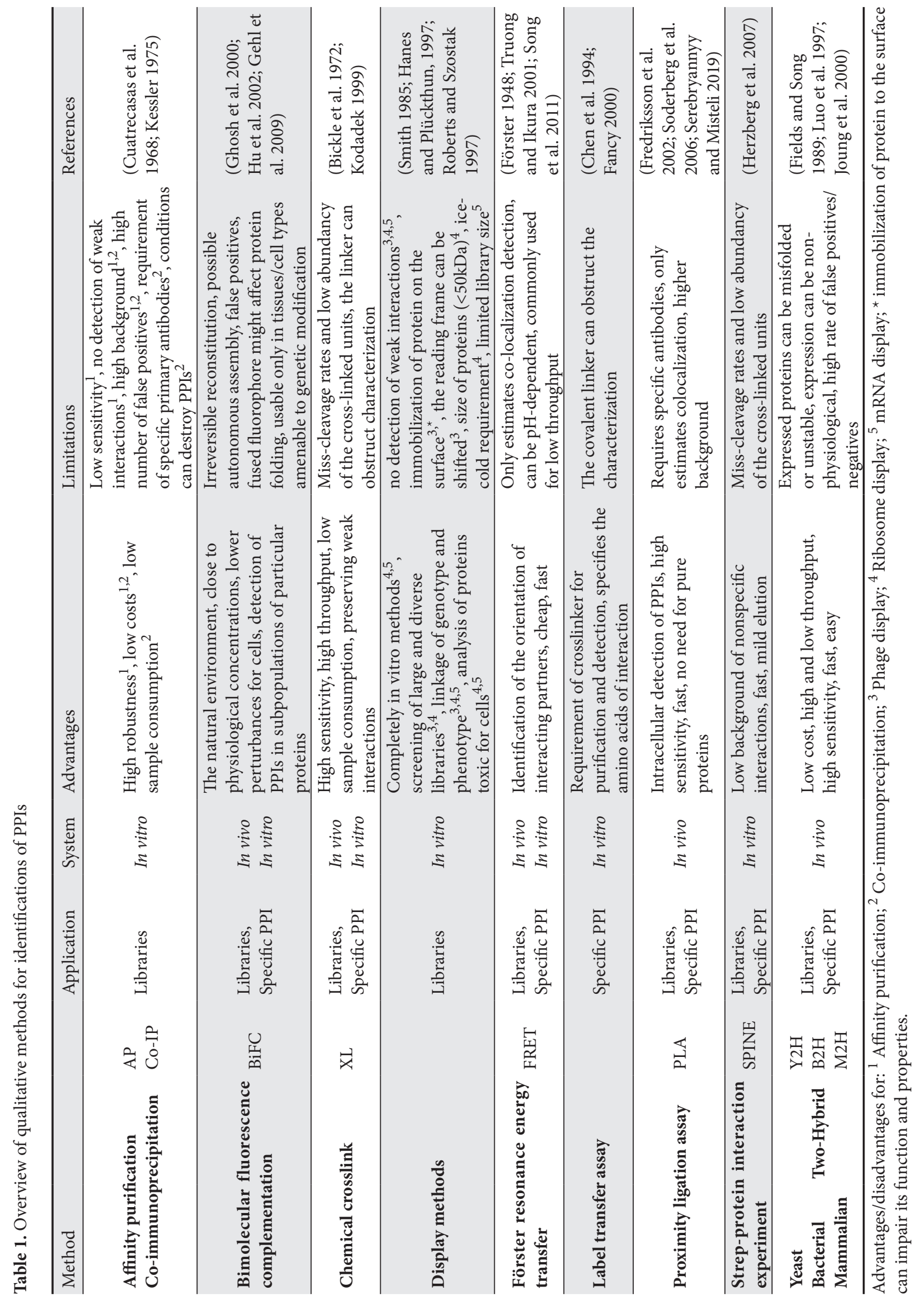




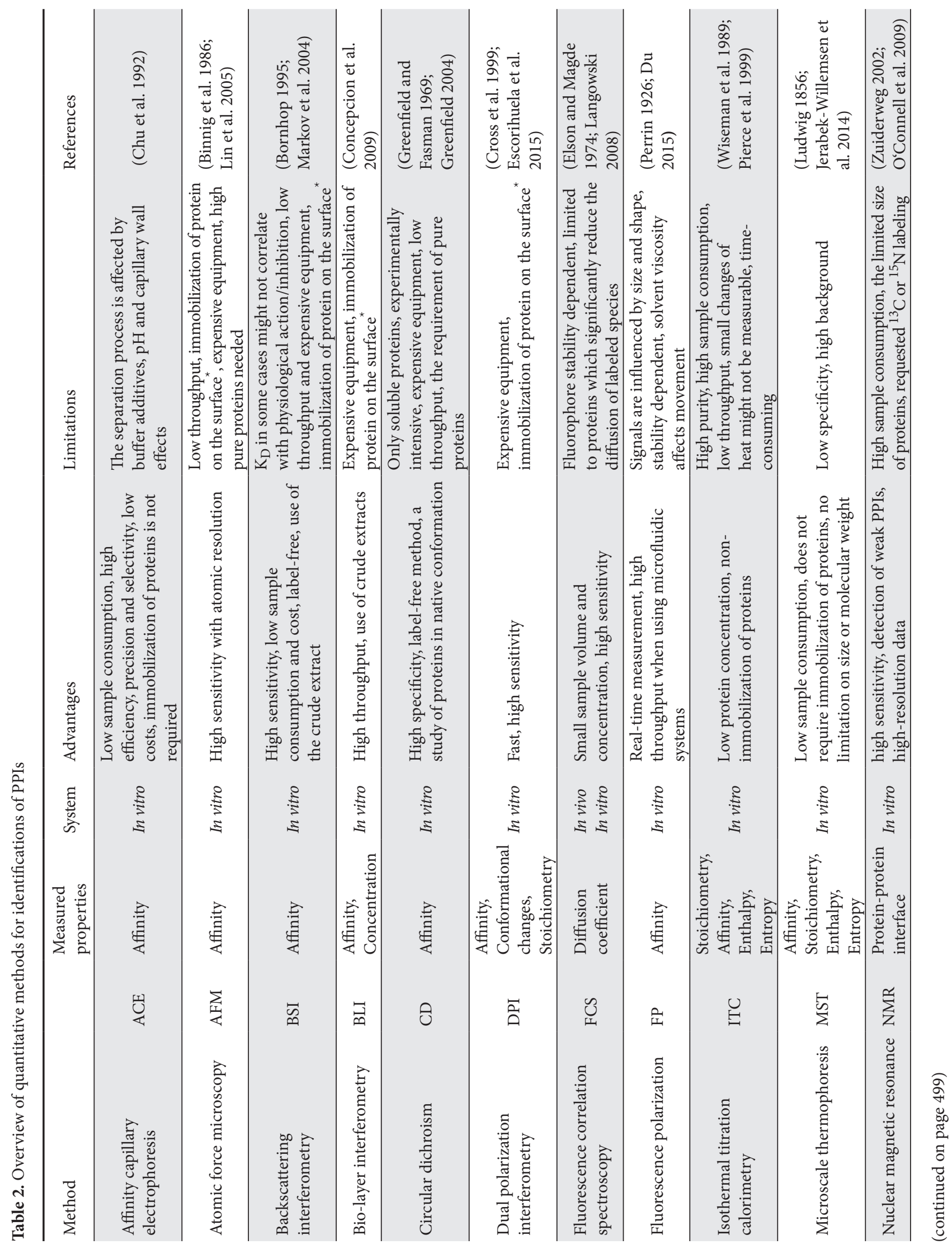


popular methods in the in vivo group are protein-fragment complementation assays (Morell et al. 2009), bimolecular fluorescence complementation (Hu et al. 2002), Yeast (Fields and Song 1989), Bacterial (Joung et al. 2000) and Mammalian (Luo et al. 1997) two-hybrid systems, Förster resonance energy transfer (Helms 2008), fluorescence correlation spectroscopy (Elson and Magde 1974), proximity ligation assay (Soderberg et al. 2006), rotating cell-based ligand binding assay (Bjorke and Andersson 2006) and single-molecule interaction microscopy (Perera et al. 2020), and several methods developed for in vivo PPIs analysis can be used also to study PPIs in vitro.

\section{Protein-fragment complementation assays (PCA)}

PCA is based on forming a bimolecular complex of two non-active fragments of a reporter protein. These fragments are fused to the studied interacting proteins (called bait and prey), and upon their interaction, the protein reporter function is reconstituted (Remy and Michnick 2007). The most common proteins utilized in PCA are ubiquitin (Johnsson and Varshavsky 1994), fluorescent proteins GFP (Ghosh et al. 2000) or YFP (Hu et al. 2002), tobacco etch virus protease (Wehr et al. 2006), luciferase (Paulmurugan et al. 2002; Remy and Michnick 2006), dihydrofolate reductase (Pelletier et al. 1998), transcription factor Gal4 (Fields and Song 1989), $\beta$-lactamase (Galarneau et al. 2002) or $\beta$-galactosidase (Rossi et al. 1997). PCA can be used for studying PPI in vivo in multicellular organisms (Kerppola 2006a), in vitro (Galarneau et al. 2002) or in living cells (Nyfeler et al. 2005). The use of some reporter genes, like $\beta$-galactosidase, may have a drawback since natural and spontaneous association of its subdomains can occur, which may result in a background noice (Galarneau et al. 2002). This drawback can be overcome by using other enzymes like, e.g., $\beta$-lactamase (Spotts et al. 2002), or luciferase. For the luciferase complementation assay, the reconstituted luciferase from Gaussia princeps (Remy and Michnick 2006), or firefly (Paulmurugan et al. 2002) is used, and its activity is measured by luminescence. This assay exhibits higher sensitivity compared to fluorescent PCAs because the cellular luminescence background is absent. Another advantage of using luciferase is that the folding of the reconstituted enzyme is fast and reversible, enabling the use of nearly real-time analysis of interaction dynamics, for example, as demonstrated in the study on the PKB-SMAD3 association upon stimulation (Remy and Michnick 2006).

The principle of bimolecular fluorescence complementation (BiFC) is the measurement of the fluorescent signal of a fluorescent protein which is reconstituted from its two nonfluorescent protein fragments fused to the interacting bait and prey (Fig. 1) (Hu et al. 2002). BiFC was first described in E. coli using green fluorescent protein (Ghosh et al. 2000) 
A

B

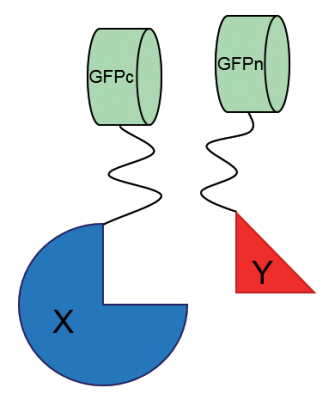

Figure 1. Bimolecular fluorescence complementation using green fluorescent protein (GFP). The bait protein $\mathrm{X}$ is fused to the $\mathrm{C}$-terminal fragment of GFP and the prey protein $\mathrm{Y}$ is fused to the $\mathrm{N}$-terminal GFP fragment. In case the bait and prey proteins do not interact, GFP stays inactive and no fluorescence can be detected (A). If the bait and prey proteins interact, functional GFP protein is reconstituted resulting in fluorescence (B).

and later adapted for the study of PPIs in yeast (Barnard et al. 2008), plant (Bracha-Drori et al. 2004), and mammalian cell systems (Remy and Michnick 2004). BiFC was used also in several rarely used model organisms, as in Acremonium chrysogenum (Hoff and Kuck 2005), Sinapis alba (Stolpe et al. 2005), Agrobacterium tumefaciens (Atmakuri et al. 2003), Bacillus subtilis (Defeu Soufo and Graumann 2006) and Magnaporthe grisea (Zhao and Xu 2007). The fluorescence intensities can be measured with a fluorometer (Zamyatnin
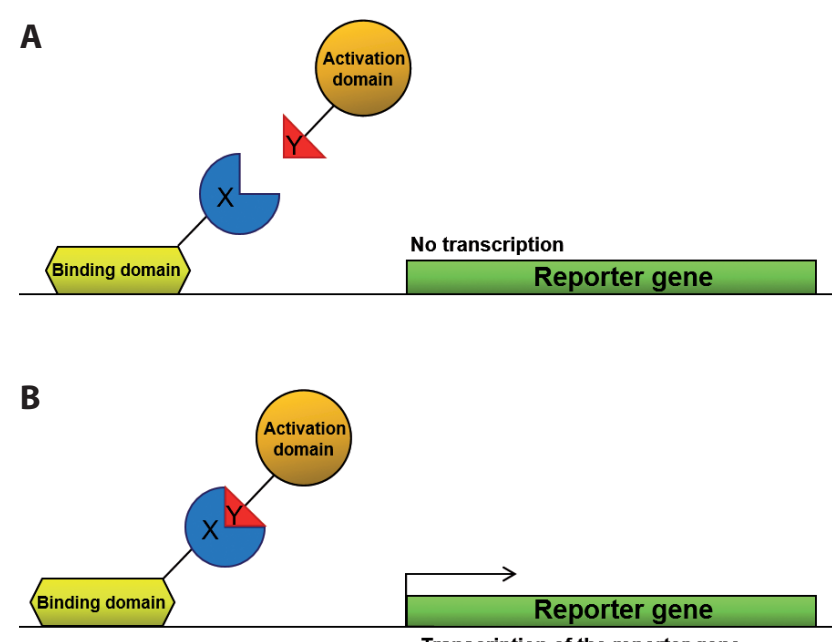

Transcription of the reporter gene

Figure 2. Two-hybrid system. Bait protein $\mathrm{X}$ is fused to a DNAbinding domain and the prey protein $\mathrm{Y}$ is fused to the transcription activation domain. If the bait protein $\mathrm{X}$ and prey protein $\mathrm{Y}$ do not interact, the reporter gene will not be expressed (A). In case the bait and prey proteins interact the reconstituted transcription factor can activate the expression of the reporter gene (B).

et al. 2006), flow cytometry (Morell et al. 2008), or can be directly visualized in subcellular locations using a fluorescence microscope (Kerppola 2006b). BiFC was also used to study PPIs in vitro, e. g. for the visualization of Ras-Raf and cofilin-actin interactions by venus fragments (Ohashi et al. 2012). For the visualization of PPIs in a nanoscale resolution, BiFC can be combined with Photoactivated Localization Microscopy (BiFC-PALM) (Nickerson et al. 2014). BiFC can be also used for high-throughput screening which is mostly used in plant models (Gehl et al. 2009).

The two-hybrid systems are currently the most preferred, popular and cost-effective approach to study PPIs in cellular models. They can be used in small-scale or high-throughput screening. The principle of two-hybrid systems is the restoration of the function of a transcription factor or another reporter protein from its non-functional split fragments, which is reconstituted by bait and prey interaction (Fig. 2). Three experimental two-hybrid-systems are currently available: A) bacterial (B2H) (Joung et al. 2000), B) yeast (Y2H) (Fields and Song 1989), and C) mammalian (M2H) (Luo et al. 1997).

A) Bacterial two-hybrid system (B2H) mainly uses Escherichia coli. In $\mathrm{B} 2 \mathrm{H}$, one protein of interest is fused to a DNA binding domain, and the second protein of interest is fused to a subunit of the E. coli RNA polymerase. The original $\mathrm{B} 2 \mathrm{H}$ utilizes hisB gene and an auxotrophic E. coli strain as a reporter (Joung et al. 2000), which was over the years modified, where new variants were developed.

Alternative $\mathrm{B} 2 \mathrm{H}$ systems can be divided into two categories:

1) Systems based on a transcriptional activation or repression of reporter genes

- In $\lambda$ cI gene repression, the $\lambda$ repressor controls the lytic/lysogeny commitment of the bacteriophage $\lambda$, which allows the inclusion of the bacteriophage DNA into the E. coli chromosome, and repression of the expression of the lytic program genes of the bacteria (Dodd et al. 2001). The $\lambda$ repressor is a dimer of two identical polypeptides, whereby each polypeptide consists of a DNA-binding domain (DBD) and a dimerization domain. The dimerization domain is replaced by both bait and prey proteins resulting in two fusion proteins: $\lambda c I$-bait and $\lambda c I-$ prey. This $\mathrm{B} 2 \mathrm{H}$ system can have two read-outs. In case the proteins of interest do interact, $\lambda$ repressor is reconstituted which represses the transcription of the reporter gene (mostly lacZ fused to the $\lambda$ promoter-operator). The second marker of interaction is the determination of the sensitivity of cells to phage infection, since the cells expressing a dimeric repressor are immune to infection. One of the drawback of the $\lambda c I$ system is that the DBD has naturally low dimerization ability, resulting in a basal level of repression activity. The 
second drawback is that it cannot be used for the screening of proteins that can homodimerize, because it will lead to repression without the bait-prey interaction (Hays et al. 2000).

- The LexA system is analogous to the $\lambda c I$ system. LexA complex consists of DBD and dimerization domains, which in physiological conditions, dimerizes and functions as a transcriptional repressor. In LexA system, the proteins of interest are fused to a DBD of LexA protein, the bait to wild-type, and prey to its mutated form (LexAm), to prevent LexA homodimerization. Additionally, also the hybrid operator is constructed, consisting of both hybrid (where only LexAm can bind), and wild type LexA binding sites. The interaction of bait and prey leads to the heterodimerization of LexA with LexAm which results in the repression of the reporter gene. The advantage of the LexA over the $\lambda$ cI system is that the LexA system has no basal repressor activity, since the engineered LexA lack the intrinsic dimerization capacity (Dmitrova et al. 1998; Daines et al. 2002).

- The repression by DNA looping assay can detect interactions between proteins, and is based on the transcriptional repression of a reporter gene by the formation of loops. The reporter gene lac $Z$ is under the transcriptional control of the araBAD promoter. In this system, the LexA operator half-sites are inserted between the araBAD promoter and the translational start of the lac $Z$ gene. The dimerization domains of both AraC and LexA are substituted by bait and prey proteins. The transcriptional activator AraC fused with bait upon binding to the AraC operator upstream from the araBAD promoter initiates the expression of lac $Z$. In case the bait and prey proteins interact, the heterodimerization of the AraC-bait and LexA-pray occurs, which leads to the concurrent binding of fused LexA to the half-sites operator and AraC to the araC operator. This results in the formation of a DNA loop that represses the araBAD promoter (Kornacker et al. 1998). The disadvantage of this system is that the fusion of bait and prey proteins to the AraC and LexA can alter their affinity for the operator sites, and thus affect the efficiency of transcriptional repression by the DNA loop formation. Moreover, the cells have to maintain three plasmids (two expression vectors and one reporter gene) simultaneously, therefore the screening is more prone to artifacts.

2) Systems based on the reconstitution of an enzyme and/ or signaling transduction pathway: mouse dihydrofolate reductase two-hybrid system, and the adenylate cyclase two-hybrid system:

- The adenylate cyclase two-hybrid system (BACTH) is based on the reconstitution of a regulatory cascade that depends on cyclic adenosine $3^{\prime}, 5^{\prime}$-monophosphate (cAMP). The system uses the $B$. pertussis adenylate cyclase catalytic domain. This enzyme consists of 1706 amino acids, of which the first 400 residues have catalytic activity. The activity domain can be divided into two sub-domains: the first subdomain, a $25 \mathrm{kDa}$ fragment (T25, residues 1-224), contains the catalytic site, and the second subdomain, an $18 \mathrm{kDa}$ fragment (T18, residues 225-399), contains the calmodulin-binding site. The bait and prey proteins are fused to either the T18 or T25 subunits of adenylate cyclase and expressed in a strain lacking adenylate cyclase (cya- strain). Upon interaction of bait and prey, the adenylate cyclase is reconstituted, cAMP is produced which subsequently interacts with the catabolic activator protein (CAP). This cAMP/CAP transcription regulation complex binds to promoters and regulates the transcription of reporter genes (maltose or lactose catabolic operons). This results in a capability to process lactose or maltose, which can be detected either on a medium containing $\mathrm{X}$-gal (resulting in a colorimetric selection), or on a selective media with added maltose or lactose as carbon sources where only bacteria expressing interacting proteins can grow (Karimova et al. 1998). The BACTH is currently the most used $\mathrm{B} 2 \mathrm{H}$.

- In murine dihydrofolate reductase (mDHFR) complementation assay, the activity of the split enzyme is reconstituted when the split parts are in close proximity, and the bait and prey proteins are fused to the split parts of the enzyme. The identification of PPI is performed in the presence of trimethoprim in media which selectively inhibits bacterial dihydrofolate reductase, and not its eukaryotic ortholog, making mDHFR essential for the growth of E. coli (Pelletier et al. 1998). This approach can also be performed in mammalian cell lines, where the mDHFR activity is detected by either cell survival, or by a fluorescence assay that uses fluorescein conjugate of methotrexate (Remy and Michnick 1999).

B) Yeast two-hybrid system (Y2H) is the first developed, and currently the most used two-hybrid system to study PPIs. It was discovered in the late 1980s using Saccharomyces cerevisiae (Fields and Song 1989). In $\mathrm{Y} 2 \mathrm{H}$ one interaction partner, the bait, is fused to the DNA-binding domain of a transcription factor, and the second interaction partner, the prey, is fused to the activation domain (AD) of the same transcription factor (Latchman 1990). Upon bait and prey interaction, the transcription factor is reconstituted, thereby regaining its activity and triggering the transcription of the reporter gene.

Currently many modifications of the $\mathrm{Y} 2 \mathrm{H}$ have been established based on yeast strains that utilize reporter genes other than lacZ (utilized in the original $\mathrm{Y} 2 \mathrm{H}$ (Fields and 
Song 1989)), that are either auxotrophic markers, or markers of phenotype sensitivity. Auxotrophic markers must be used with modified yeast strains that are auxotrophic for the particular marker, for example, LEU2, HIS3, ADE2, URA3 (Van Criekinge and Beyaert 1999), LYS2 (Serebriiskii et al. 1999), CYH2 (Leanna and Hannink 1996). The Y2H has many advantages, among them: a) eukaryotic system which is similar to the natural environment, b) cheap, c) possibility for high throughput, d) highly sensitive e) timeefficient, and f) easy to perform. On the other hand, there are several drawbacks: a) since the interactions takes place in the nucleus the proteins must be soluble b) possible incorrect structure of proteins of interest due to missing mammalian folding cofactors, c) fused proteins may cause incorrect protein folding or instability, d) proteins could be expressed at non-physiological levels, e) post-translational modifications of proteins from different species might not occur appropriately in yeast, and e) potential occurrence of false positives and/or negatives, which requires additional validation experiments.

Besides the development of $\mathrm{Y} 2 \mathrm{H}$ using different reporter genes, several alternative systems with different mechanisms have been established and are described below.

The interaction trap (Gyuris et al. 1993), also known as the LexA system, uses the bacterial LexA repressor binding domain as $\mathrm{DBD}$ fused with the bait. The prey protein is fused with the activation domain of the E. coli B42 protein (also called as acid blob). The yeast strain used contains two LexA-operator responsive reporters: a LexAop-GAL1-LacZ plasmid, and a LexAop-LEU2 gene present in a single copy on the chromosome. The DBD-bait protein is constitutively expressed by the plasmid, and the expression of the AD-prey is induced by addition of galactose. In glucose medium, only the DBD-fused protein is expressed, which is unable to activate the expression of reporter genes; therefore, yeasts do not grow on glucose medium lacking leucine. In a galactose medium, the expression of $\mathrm{AD}$-prey is induced, and upon interaction with DBD-bait, the yeasts are able to grow without leucine, and have blue color in the presence of X-gal (Gyuris et al. 1993). The advantage of this system is the utilization of a Gall inducible promoter for the ADprey expression, which can be used in the study of toxic proteins in yeast.

The split-ubiquitin $\mathbf{Y} \mathbf{2 H}$ was developed as a solution to overcome the drawback of the classical $\mathrm{Y} 2 \mathrm{H}$ which requires the interaction of studied proteins in the nucleus. The splitubiquitin $\mathrm{Y} 2 \mathrm{H}$ works in the cytoplasm and utilizes the ubiquitin protein, whose natural role is marking of proteins for the degradation by the ubiquitin-specific protease. The ubiquitin is split into two non-functional fragments, the modified $\mathrm{N}$-terminal ubiquitin domain, without the natural affinity for the C-terminal region, is fused to prey protein, and bait is attached to C-terminal fragment conjugated with murine dihydrofolate reductase (mDHFR). When bait and prey interacts, functional ubiquitin is reconstituted, mDHFR fused to the C-terminal of ubiquitin is cleaved and released, which can be observed by immunoblot analysis (Johnsson and Varshavsky 1994). For better readout of the split-ubiquitin $\mathrm{Y} 2 \mathrm{H}$ easier three modifications have been developed: a) split-ubiquitin $\mathrm{Y} 2 \mathrm{H}$ with rUra3p reporter protein, b) membrane yeast two-hybrid system or c) cytosolic yeast two-hybrid system.

In the split-ubiquitin $\mathrm{Y} 2 \mathrm{H}$ with $\mathrm{rUra3p}$ reporter protein, instead of mDHFR, the system uses URA3 gene, an enzyme essential for the production of uracyl. Additionally, rUra3p protein is modified to be vulnerable for degradation by endogenous proteases. This enzyme is also able to convert 5-fluoroorotic acid (5-FOA) to a toxic metabolite that causes cell death. In this system, if bait and prey interacts, rUra3p protein is cleaved from ubiquitin C-terminal fragment, and subsequently degraded. The system has two alternative read-outs upon bait and prey interaction: a) yeast colonies can grow on a medium containing uracyl and 5-FOA, and b) yeast colonies cannot grow on a medium without uracyl (Laser et al. 2000).

If membrane proteins are expressed in the cytoplasm, they are very often insoluble and/or malfunctional. Therefore, the split-ubiquitin based membrane yeast two-hybrid system (MbY2H) was developed. MbY2H is suitable for the study of interactions between membrane proteins that have at least one domain localized in the cytosol. Here, the bait membrane protein is fused to the C-terminal ubiquitin moiety conjugated to transcription factors LexA-VP16 (VP16 is a transcriptional activator from herpes simplex virus, (Sadowski et al. 1988). The prey membrane protein is fused with the N-terminal ubiquitin moiety. Upon interaction of bait and prey, split-ubiquitin is reconstituted, recognized by ubiquitin-specific protease and the protein complex is cleaved. Subsequently, the liberated transcription factor enters the nucleus, binds to LexA-binding sites in the promoter region, and induces transcription of reporter genes HIS3 and lacZ (Stagljar et al. 1998).

The split-ubiquitin $\mathrm{Y} 2 \mathrm{H}$ was also adapted for the screening of cytosolic proteins to overcome their interaction in the nucleus. In the cytosolic yeast two-hybrid system (cyto $\mathbf{Y} 2 \mathrm{H}$ ), the bait fused to the C-terminal ubiquitin moiety with an artificial transcription factor LexA-VP16 is anchored to the endoplasmic reticulum membrane by the fusion with the Ost $4 \mathrm{p}$ protein. The prey attached to a mutated $\mathrm{N}$-terminal ubiquitin moiety is expressed freely in the cytoplasm. In the case of bait and prey interaction, the mechanism of reporter gene activation is identical to $\mathrm{MbY} 2 \mathrm{H}$. The LexA-responsive reporter genes are in this case HIS3, ADE2 and lacZ which are integrated in the genome. This system can be used also for the identification of transcriptional activators (Mockli et al. 2007). 
The advantages of the split-ubiquitin $\mathrm{Y} 2 \mathrm{H}$ are a) the screening for interaction is mediated by the cleavage of ubiquitin, b) because the ubiquitin is a small molecule, its steric hindrance for interacting proteins is low, and c) the interaction need not be carried out in the nucleus (Johnsson and Varshavsky 1994).

RAS recruitment system (RRS) is able to bypass the transcriptional readout using the Ras signaling pathway, which is homologous between mammals and yeasts. The Ras system is based on two factors a) the Ras has to be localized at the plasma membrane $b$ ) it has to be activated by the guanyl exchange factors (Cdc25 in yeast, and son of sevenless (SOS) in mammals) to undergo a GDP-GTP exchange. A soluble bait protein is fused to an activated mammalian Ras. The prey protein is associated with the membrane, e.g. by myristylation. If the bait and prey do interact, the Ras activates downstream signaling, which results into rescue of the temperature-sensitive $c d c 25$ yeast strain, which will be able to grow at $36^{\circ} \mathrm{C}$ (Broder et al. 1998).

The reverse Ras recruitment system (rRRS-Y2H) is based on the same principle as RRS, with the difference that the bait is an integral membrane protein, and the prey protein is a soluble protein fused to active Ras (Hubsman et al. 2001).

The SOS recruitment system (SRS-Y2H) also works similarly. The prey protein is fused to the membrane with an anchor (via myristylation). The non-active yeast Ras is localized at the membrane. A soluble bait protein is fused to the mammalian SOS. In the case that bait and prey interact, the SOS stimulates the Ras resulting in the downstream signaling (Aronheim et al. 1997).

The reverse two-hybrid system $(\mathbf{r Y 2 H})$ is built on the classical $\mathrm{Y} 2 \mathrm{H}$ with the difference that the expression of the reporter gene leads to the generation of products that are toxic to the yeast. The rY2H utilizes a counter-selection strategy where the disruption of an established PPI leads to cell viability. The reporter gene URA3 is used as a counterselection marker, because in the presence of 5-FOA, the enzyme orotidine 5 '-phosphate decarboxylase, which is the product of the URA3 gene, converts this substrate to a toxic metabolite that causes cell death. This system can be used for the identification of compounds that inhibit the bait-prey interaction. In case of the inhibition of the interaction in the presence of the toxic metabolite (5-FOA) the viability of the cells is rescued (Vidal et al. 1996). Another alternative rY2H utilizes the $c y h 2$ reporter gene, in which the interaction of bait and prey, restores the sensibility to cycloheximide in a resistant strain (Leanna and Hannink 1996). rY2H can be used to identify residues required for protein-protein interaction by using a mutated copy of the cDNA encoding one of the proteins. cDNAs encoding proteins are then no longer able to interact, and can be sequenced to identify amino acids essential for interaction. $\mathrm{rY} 2 \mathrm{H}$ can be also used for the identification of molecules that are able to dissociate known interactions (Vidal et al. 1996).

In the dual bait system (Serebriiskii et al. 1999), two baits to one prey protein are used. Commonly two different bait proteins (X1 and X2) are fused to two different DBD (e.g. LexA and $\lambda \mathrm{CI}$ ), and are co-expressed in the same cell. Both DBDs activate a different set of reporter genes. The interaction of the prey protein with one of those bait proteins starts the transcription of either LexA-dependent reporter genes (lacZ and LEU2) if interacting with X1 bait protein, or $\lambda c I-$ dependent reporter genes (gusA and LYS2) if interacting with $\mathrm{X} 2$ bait protein. If prey interacts with bait protein $\mathrm{X} 1$ and activates the LexA-dependent reporter genes, the positive interaction results in colorimetric selection on a medium containing X-gal, or the possibility to grow on a minimal medium lacking leucine. In the case that the prey protein interacts with X2 bait protein, $\lambda$ cI-dependent reporter genes are activated, and can be visualized by a colorimetric selection on a medium containing X-gluc, or growth on a minimal medium lacking lysine. The dual bait system is also able to differentiate higher versus lower affinity interactions. The advantage of this system is that the controls for false positive or nonspecific interactions can be incorporated in a single step, and the system allows the simultaneous analysis of protein interaction with two related or unrelated partners in a single cell; therefore, useful for a variety of high throughput and genome-oriented studies.

The $\mathrm{Y} 2 \mathrm{H}$ has seen many modifications in the last two decades, in order to mitigate the drawbacks of the original system. Besides above mentioned modifications, five less frequently used variants of $\mathrm{Y} 2 \mathrm{H}$ have been developed: the G-protein signaling-based Y2H (Ehrhard et al. 2000), RNA polymerase III-based two-hybrid system (Marsolier et al. 1997), extracellular proteins system (SCINEX-P) (Urech et al. 2003), Split-Trp system (Tafelmeyer et al. 2004) and repressed transactivator system (Hirst et al. 2001).

The yeast three-hybrid system was developed to study three interacting partners (Zhang and Lautar 1996). Using this system, it is possible to detect Z-protein-mediated X/Y interaction, which cannot be performed with two-hybrid systems. The interactions of proteins in two-hybrid systems can be missed if a third protein is required for the interaction of these proteins, or if a protein interacts with a domain formed through the interaction of two other proteins. The principle is similar to $\mathrm{Y} 2 \mathrm{H}$, where two proteins are fused to the DBD and AD of the Gal4 transcription factor, while the third protein is expressed with only a nuclear localization signal. The activities of both reporter genes lacZ and HIS3 are only detected if all three proteins come together and form a complex (Zhang and Lautar 1996). This system can be used to study ligand-dependent receptor dimerization (Licitra and Liu 1996), or interactions between hybrid RNA molecules and proteins (SenGupta et al. 1996). 
C) Mammalian two-hybrid system (M2H) utilizes the same strategy/principle as the $\mathrm{Y} 2 \mathrm{H}$. The bait is fused to the transcription factor Gal4 DBD and the prey to the $\mathrm{AD}$ of the VP16 protein. The reporter gene used in the original M2H is chloramphenicol acetyltransferase (cat) which is under the control of five copies of the Gal4 binding sites upstream of an E1b promoter. The interaction of bait and prey proteins can be measured by the CAT assay (Luo et al. 1997). Similar to the $\mathrm{Y} 2 \mathrm{H}$ and the $\mathrm{B} 2 \mathrm{H}$, several modified $\mathrm{M} 2 \mathrm{H}$ have been developed over the last two decades, and can be classified into three categories: LUMIER (Barrios-Rodiles et al. 2005), MAPPIT (Eyckerman et al. 2001), and Split-TEV assay (Wehr et al. 2006).

- The luminescence-based mammalian interactome mapping (LUMIER) method was developed to enable an automatic high-throughput analysis for systematical mapping of PPI networks in mammalian cells. LUMIER is based on the co-expression of two interacting proteins, of which bait contains a FLAG-tag, enabling immunoprecipitation, and the prey is fused to a Renilla luciferase, enabling luminescent detection of the interaction. After anti-Flag affinity purification, the luciferase activity is measured and compared to the negative control, for example, eluate from the non-affinity matrix. In the case, the proteins do interact the activity of luciferase is higher compared to the negative controls (Barrios-Rodiles et al. 2005).

- The mammalian protein-protein interaction trap (MAPPIT) is a modification of the $\mathrm{M} 2 \mathrm{H}$ in which the PPIs takes place in an in situ environment. The bait and prey proteins are fused to fragments of a cytokine receptor (CR). The bait protein is fused to a signaling-deficient $\mathrm{CR}$, and the prey protein is tethered to a CR with an intact recruitment site. Upon bait-prey interaction, the function of the receptor is restored and can be activated with an appropriate ligand. After ligand binding, preassociated Janus kinases (JAK) are activated by crossphosphorylation. Activated JAKs phosphorylate tyrosine residues of the receptor fragment coupled to the prey, which then act as docking sites for signal transducers and activators of transcription (STATs). Recruited STATs are, in turn, phosphorylated by the JAKs, what leads to their activation, subsequent dissociation from the docking sites and dimerization. The dimers are translocated to the nucleus where they induce STAT-dependent reporter gene transcription. Besides the bait-prey interaction, the reporter gene expression also depends on the addition of the proper cytokine ligand, which adds an extra layer of control over false positives. Since the read-out depends on activated STATs which are shuttled from the cytosol to the nucleus, the procedure depends on interactions occurring in the cytosol near the membrane (submembrane space). Other advantages of the MAPPIT are that the PPIs can be detected even in the presence of endogenous proteins, and that it does not rely on the nuclear translocation of bait and prey. The MAPPIT is suitable for the analysis of signal transduction cascades because the interaction occurs in the most physiologically relevant conditions, and also because modification-dependent PPIs can be detected (Eyckerman et al. 2001).

- The principle of the split-TEV assay is based on the reconstitution of a proteolytic activity which can drive a reporter system of choice, rather than the reporter itself. Proteins of interest are fused to two fragments of the tobacco etch virus protease (TEV). Upon protein-protein interaction, protease activity of TEV is reconstituted, which cleaves a specific TEV recognition sequence. This results in either a proteolytic liberation and activation of a reporter enzyme, such as, luciferase, or releasing a transcription factor which is transported to the nucleus and activates a reporter gene (Wehr et al. 2006). The advantage of this system is the ability to identify even weak and transient interactions, or interactions dependent on low abundant endogenous posttranslational modification systems, due to the irreversible reporter activation by TEV cleavage. It is possible to study PPIs of lower expression levels which would not be possible in the classical two-hybrid system. A disadvantage is that capturing of interaction kinetics is not possible since the system is irreversible (Wehr et al. 2006).

Two-hybrid systems using other model organisms were also developed using different model systems than those discussed above. The plant two-hybrid system (P2H) utilizes protoplasts of Arabidopsis thaliana (Ehlert et al. 2006). P2H system uses a strong $35 \mathrm{~S}$ promoter for the control of Gal4 $\mathrm{AD}$ and $\mathrm{BD}$. The reporter gene used in this system is GUS ( $\beta$-glucuronidase), which upon expression is measured by the GUS assay (Ehlert et al. 2006). The neuronal $2 \mathrm{H}$ system was developed in the neurons of Aplysia californica, and utilizes the GAL4 system with a lacZ reporter gene to study long-term memory (Choi et al. 2003). The insect two-hybrid system was established in a silkworm Bombyx mori. It utilizes the Gal4 $\mathrm{BD}$ and the $\mathrm{AD}$ from a mouse nuclear factor-kappa $\mathrm{B}$ (NF- $\mathrm{kB}$, also called p65), whereby both are under the control of the OpIE2 promoter. The reporter gene of the system is the firefly luciferase (Mon et al. 2009). Each of the three discussed two hybrid systems $(\mathrm{Y} 2 \mathrm{H}, \mathrm{B} 2 \mathrm{H} . \mathrm{M} 2 \mathrm{H})$ does have advantages and disadvantages, which are described in Table 3.

\section{Förster and bioluminescence resonance energy transfer}

Förster resonance energy transfer (FRET) method was developed as a microscope method utilizing the FRET phenomenon (Förster 1948), and is more accurate in providing co-localization information in comparison to fluorescent microscopy. FRET was established as a spectroscopic ruler in the 1960s to reveal proximity relationships of two 
Table 3. Comparison of different two-hybrid systems

\begin{tabular}{lll}
\hline Two-hybrid systems & Advantages & Limitations \\
\hline $\begin{array}{l}\text { Yeast two-hybrid } \\
\text { system }\end{array}$ & $\begin{array}{l}\text { Cheap, post-translational modification of eukaryotic } \\
\text { proteins, high sensitivity }\end{array}$ & $\begin{array}{l}\text { Less suitable for membrane proteins, the possibility } \\
\text { of improper folding and/or posttranslational } \\
\text { modifications, high rates of false positives/negatives, } \\
\text { the levels of expression might be too low }\end{array}$ \\
\hline $\begin{array}{l}\text { Bacterial two-hybrid } \\
\text { system }\end{array}$ & $\begin{array}{l}\text { Screening of larger libraries compared to Y2H, } \\
\text { higher transformation efficiencies and faster growth, } \\
\text { no nuclear tag required, nor eukaryotic activation } \\
\text { domains }\end{array}$ & $\begin{array}{l}\text { The absence of posttranslational machinery might } \\
\text { lead to improper folding }\end{array}$ \\
\hline $\begin{array}{l}\text { Mammalian two- } \\
\text { hybrid system }\end{array}$ & $\begin{array}{l}\text { A suitable environment for human proteins, less time } \\
\text { costly compared to Y2H }\end{array}$ & $\begin{array}{l}\text { Not suitable for the screening of libraries, only few } \\
\text { mammalian cloning systems are available }\end{array}$ \\
\hline
\end{tabular}

fluorescence-labeled sites in biological macromolecules (Stryer and Haugland 1967; Stryer 1978). In FRET, a donor chromophore is excited upon irradiation with light at a specific wavelength, which transfers its nonradiative energy to an acceptor chromophore through nonradiative dipole-dipole coupling (Lakowicz 1999; Helms 2008). The energy transfer can happen only if donor and acceptor chromophores are in close proximity, leading to the emitting of acceptors characteristic fluorescence (Truong and Ikura 2001) (Fig. 3). In FRET, the donor and acceptor chromophores are covalently coupled to either the bait or prey proteins. Chromophores could be either small fluorescent dyes or fluorescent proteins (Sapsford et al. 2006; Stepanenko et al. 2011). Following predispositions have to be met for successful FRET: a) the overlap of donor emission and acceptor absorption spectrum must be significant and sufficient for energy transfer, b) emission spectrum of acceptor must be different from that of a donor, c) the distance between the acceptor and donor has to be less than $10 \mathrm{~nm}$, and d) the dipole orientation of the acceptor and donor has to be aligned, ideally in a parallel fashion (Sun et al. 2011). FRET can also be applied for high-throughput screenings (Song et al. 2011).

FRET is also able to inform on the orientation of interacting partners (Dos Remedios and Moens 1995), for example, as demonstrated for the interaction of a serotonin transporter with calmodulin kinase II $\alpha$ (Steinkellner et al. 2015). The disadvantage is that, although this method can be used for the co-localization of PPIs, it still does not necessarily prove a direct physical interaction. FRET could instead result from the proximity of proteins, for example in multiprotein complexes (Xing et al. 2016).

Currently, the most commonly used FRET methods are FRET-AB and FRET-FLIM. The FRET-AB method, also called acceptor bleaching FRET, measures donor quenching in the presence of an acceptor. The rationale behind this approach lies in the loss of energy transfer from the donor to the acceptor when bleached, resulting in an increase in donor fluorescence intensity and lifetime.
The measurement is accomplished by the comparison of the donor fluorescence intensity in the sample before and after the destruction of the acceptor with photobleaching (Kenworthy 2001), for example, as in the study of a nonspecific lipid transfer protein with fatty acid oxidation enzymes in peroxisomes (Wouters et al. 1998). Acceptor photobleaching is a straightforward method that does not require high-end microscopes, and the analyzed sample can serve as the additional control of the interaction. The drawback of FRET-AB is that the photobleaching of the acceptor can also bleach the donor.

For the monitoring of dynamic events in the FRET, the fluorescence lifetime imaging FRET (FRET-FLIM) was developed. FLIM is based on the measurement of nanoseconds long excited state of fluorophores within the cell which depends on the local environment surrounding the probe. The FRET-FLIM combination also enables the study
A

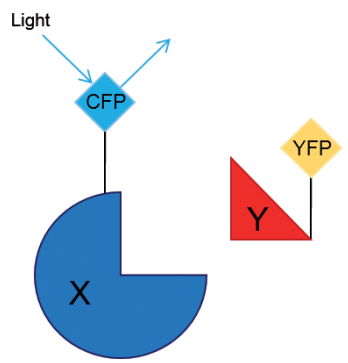

B

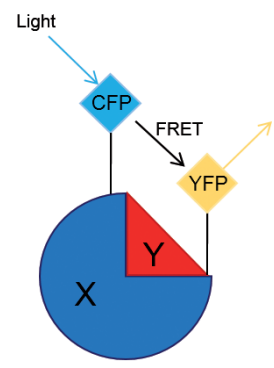

Figure 3. Förster resonance energy transfer. Two chromophores, in this case, cyan fluorescent protein (CFP) and yellow fluorescent protein (YFP), are fused to the bait protein $\mathrm{X}$ and prey protein $\mathrm{Y}$. If the bait $\mathrm{X}$ and prey $\mathrm{Y}$ proteins do not interact the energy transfer from the excited CFP to YFP will not happen (A). If the bait X and prey $\mathrm{Y}$ protein interact, CFP and YFP are in close proximity and the emission energy from excited CFP is transfer to YFP what results in the emission of fluorescence (B). 
of dynamic PPIs in 2 to 3-dimensions (Elangovan et al. 2002; Chen and Periasamy 2004).

Several other FRET modifications have been also developed, for example, spectral FRET (Neher and Neher 2004), single-molecule fluorescence resonance energy transfer (smFRET) (Ha et al. 1996; Ha 2001), and homo-FRET (Yeow and Clayton 2007; Bader et al. 2009). Besides, a single-molecule three-color FRET was also built, which utilizes two acceptor fluorophores instead of one. The three-color FRET allows studying of three different interaction partners, and can provide three-dimensional spatial and temporal information on protein-protein interactions and complexes in single living cells under physiological conditions (Hohng et al. 2004; Kim and Chung 2020). FRET and some of its modifications can be also applied for in vitro studies of PPIs (Elvekrog and Gonzalez Jr 2013).

Bioluminescence resonance energy transfer (BRET) is based on a similar principle like FRET. The only difference is that the resonance energy is transferred from an excited bioluminescent donor (commonly luciferase) to a fluorescent acceptor. For the activation and excitation of the bioluminescent donor, a substrate is required (Xu et al. 1999; Dimri et al. 2016).

Fluorescence correlation spectroscopy (FCS) and fluorescence cross-correlation spectroscopy (FCCS)

FCCS is a quantitative method used for the characterization of PPIs in living cells. It was modified from FCS (Elson and Magde 1974), which is mainly used for PPIs studies in vitro. The FCS is based on the excitation of fluorescently labeled molecules in a small volume (femtoliters), whose diffusion out and into the detection volume causes a fluctuation of fluorescence intensity, which is measured. After a fluorescently labeled molecule binds to its interaction partner, its mobility is slowed, which is reflected in its fluctuation rate (Langowski 2008). FCS can also determine the concentration and mobility (diffusion coefficient) of free interacting proteins (Langowski 2008; Dawes et al. 2020). FCS can be applied in vivo for qualitative confirmation of PPIs, for example, as described in the interaction of human immunodeficiency virus type 1 integrase with lens epithelium-derived growth factor/transcription co-activator p75 (Maertens et al. 2005).

FCCS (Eigen and Rigler 1994; Schwille et al. 1997) can assess several additional parameters that cannot be measured by the FCS. It can determine the affinity, enzyme kinetics (Kettling et al. 1998) and oligomerization of the binding (Bacia et al. 2006). In comparison to FCS, the FCCS uses two spectrally distinct fluorophores for the labeling of interaction partners. After the interaction of proteins, the molecules diffuse through the focal volume in a synchronized manner, inducing simultaneous fluctuations of the fluorescence signals in the two-color channels, resulting in a positive cross-correlation readout (Bacia et al. 2006).

Both the FCS and FCCS methods can also be used in in vitro studies (Schwille et al. 1997; Kettling et al. 1998; Van Craenenbroeck and Engelborghs 1999).

\section{Proximity ligation assay (PLA)}

PLA (Fredriksson et al. 2002) is a method utilizing antibodies, nucleotides and fluorescence, and is used for the intracellular detection of PPIs. Protein partners of interest are first expressed in cells, which are fixed, permeabilized, and labeled with each protein-specific antibody, tagged with different short DNA oligonucleotide. After washing, the linear connector oligonucleotide is added. In the case that bait and prey interact, both PLA probe-oligonucleotides are annealed with linear connector oligonucleotide, consequently forming a circular structure that is covalently ligated (Soderberg et al. 2006). Subsequently, rolling circle amplification (RCA) is initiated, where one of the probes is used as a primer. Amplified DNA is detected by hybridization of a fluorescently labeled oligonucleotide complementary to a tag sequence in the RCA product, which can be analyzed by fluorescent microscopy. In this way, a single-molecule sensitivity can be achieved (Soderberg et al. 2006; Jarvius et al. 2007). Alternatively, the visualization of PPIs in PLA can be also achieved by the combination of unmodified primary antibodies from different species with secondary antibodies tagged with short DNA oligonucleotides (Jarvius et al. 2007). PLA was recently applied in a high-throughput screening set-up for the identification of interaction partners of the nuclear lamina (Serebryannyy and Misteli 2019).

\section{Rotating cell-based ligand binding assay}

This method can be used for the analysis of interaction of proteins expressed on the surface of cells with their ligands, and it has been widely used for the study of receptor-ligand interactions (De Jong et al. 2005). The assay works as follows: petri dish with the solid medium is divided into an active area, with target cells expressing the receptor, and reference area (lacking target cells). The solution with the radioactively labeled studied interacting partner (ligand) is added to obtain a homogenous solution on both areas of the petri dish. The activity of both areas are separately measured and compared. Using this method, it is possible to measure the association, dissociation, and affinity constants of PPIs (Bjorke and Andersson 2006).

\section{Single-molecule interaction microscopy (SMIM)}

SMIM is a method used for the quantitative study of PPIs inside the cell, focusing mostly on antibodies. It is based 
on the merge of point accumulation for imaging in the nanoscale topography (PAINT) method with extended imaging duration, enabled by inserting non-illuminating intervals between image frames (Perera et al. 2020). PAINT is a process that uses fast and transient dyes to capture several fluorescence points at once. If a fluorescently labeled prey binds to the immobilized bait a fluorescent signal appears as a diffraction-limited spot. This signal is destroyed after label dissociation or photo bleaching (Sharonov and Hochstrasser 2006; Giannone et al. 2010).

Overall, the in vivo methods do have many advantages over in vitro techniques. The environment of the interaction is closer to the physiological state in in vivo methods. Most of the methods can have high throughput, which makes them useful for large library screenings. The strength of these methods is the fact that, in most cases, no expensive infrastructure is required, and most of them (e.g. BiFC, FCS, FRET) have high sensitivity. The drawbacks are mainly the high rate of false positives or non-specific interactions.

\section{In vitro methods}

The second group of methods used for the study of PPIs are the in vitro methods, which are carried out outside of the organisms and their natural environment, very often using purified proteins. Many methods in this group can qualitatively describe interactions, and several of them can measure also quantitative parameters. With the qualitative methods, it is possible to screen for PPIs using libraries or confirm already discovered PPIs. The quantitative methods are able to measure several different properties of the PPIs. For example, the affinity constants, stoichiometry, enthalpy, entropy, and even properties like charge or molecular weight. Many of the original methods developed for in vitro studies have been also modified for in vivo systems. The in vitro methods have many advantages as they are fast, cheap, and in most cases they require a small amount of samples. The disadvantage of the in vitro systems is that the environment of the PPIs is different compared to the natural environment where the PPIs occur, which can lead to false positives. However, the advantages of in vitro methods in most cases outweigh their disadvantages. They are very often used for validation of interactions identified by in vivo systems, like for example two-hybrid systems.

\section{Affinity chromatography and co-immunoprecipitation (co-IP)}

Affinity chromatography (also called affinity purification) and co-immunoprecipitation are currently the basic biochemical approaches to the qualitative study of PPIs in an in vitro environment.

By affinity chromatography, bait protein is covalently immobilized on a matrix (affinity resin). Alternatively, also non-covalent immobilization is possible, but in a high affinitive manner, such as, the biotinylated protein is immobilized on a streptavidin column (Green 1990; Qureshi and Wong 2002). Lysate from cells or tissue is then applied to the affinity column and all prey proteins interacting with the immobilized bait are captured. After washing, the captured prey proteins are eluted (Cuatrecasas et al. 1968) by the addition of suitable agents, such as, related competitor ligand, high salt concentration, change of $\mathrm{pH}$, detergent, etc (Ratner 1974). The analysis and identification of bound proteins can be carried out by mass spectrometry (Gingras et al. 2007; Collins and Choudhary 2008), immunoblot analysis (Bochar et al. 2000), etc. Several types of PPIs could be identified by affinity chromatography, for example, antibody-antigen (Olmsted 1981), enzyme-substrate (Duckworth et al. 1972), enzyme-cofactor (Lowe and Dean 1971), enzyme-inhibitor (Chijiwa et al. 1989), and ligand-receptor (Cull et al. 1992).

co-IP (Kessler 1975) is based on a similar principle as affinity chromatography. Interacting proteins are isolated from cell or tissue lysates with the help of antibodies specific for bait protein. The antibody is added to the sample, and the antibody-bait-prey complexes are isolated by e.g. protein-G (Akerström et al. 1985), or protein-A (Yaciuk 2007) magnetic or agarose beads which specifically bind antibodies. In case the co-IP is performed from antibody-containing samples (e.g. blood or some tissues), a lot of "unwanted" naturally present antibodies are also retained, which decreases the amount of purified specific complexes. This drawback can be overcome if the antibody is covalently coupled to magnetic or agarose beads, and subsequently used for immuno pull-down of bait-pray complexes. After washing of beads, the complexes can be eluted, analyzed, and identified by mass spectrometry, Western blot, or other methods (Lin and Lai 2017).

\section{Chemical cross-linking, label transfer and strep-interaction experiment (SPINE)}

Chemical cross-linking (Bickle et al. 1972; Han et al. 1984; Fancy and Kodadek 1999) emerged as a method that helps to not only identify weak PPIs in vitro (Selkoe et al. 1982), but can be used also for the identification of interacting partners in vivo (Schmitt-Ulms et al. 2004). The chemical crosslinking is based on the introduction of a covalent bond between amino acids in close proximity, between two proteins, or functional groups of one protein (gaining insights over the protein conformation) using chemical reagents called crosslinkers (Tang and Bruce 2009). Subsequently, the cross-linked complexes are purified and analyzed by biochemical methods (Western blot, ELISA, etc.), but most often by mass spectrometry (MS). In Cross-Linking Mass Spectrometry technology (XL-MS), either whole crosslinked protein complexes are analyzed by multiple stages of 
fragmentation in the mass spectrometer (so-called top-down approach) (Fig. 4) (Kruppa et al. 2003), or complexes are first cleaved by proteases and then peptides are analyzed by MS (bottom-up) (Young et al. 2000). The XL-MS method does have few obstacles. First, the miscleavage rate during enzymatic digestion could be increased, since the cleavage sites are often blocked by the crosslink, leading to increased peptide size. Secondly, the abundance of the cross-linked peptides compared to linear peptides is low. Therefore, the right choice of the linker in crosslinking reagent has to be considered, since it influences the positions where the cross-link is created, and the number of cross-links. The chemical crosslinkers commonly used are formaldehyde, amine-reactive crosslinkers, sulfhydryl reactive crosslinkers, or photoreactive crosslinkers (reviewed in (Sinz 2003)). For the top-down approach, several new cross-linkers have been developed, which are MS-cleavable. For example, DC4, DHSO, BMSO, and many more (for a comprehensive review, we refer the readers to the article (Matzinger and Mechtler 2020)). The crosslinking is also possible to perform in vivo in cell models or higher organisms to study PPIs in their native environment. In the in vivo approach, the PPIs are first cross-linked in living cells or model organisms, for example, by perfusion with a solution containing crosslinker. The PPIs are isolated, cleaved by proteases and analyzed by MS (Schmitt-Ulms et al. 2004). This approach was applied for the identification of amyloid peptide (Schmitt-Ulms et al.

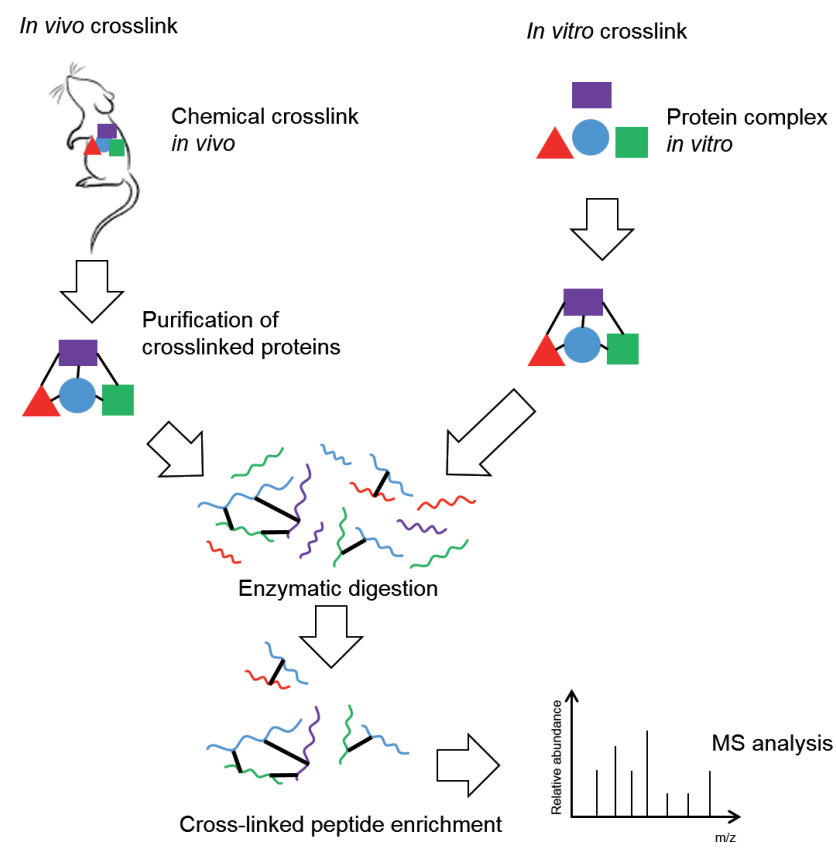

Figure 4. Chemical cross-linking. In the first step, protein complexes are crosslinked in vivo or in vitro by a cross-linker. The complexes are subsequently purified and enzymatically digested to peptides which are analyzed by mass spectrometry (MS).
2004), and tau protein interaction partners (Schmitt-Ulms et al. 2004; Sinsky et al. 2020). Using the XL-MS method, it is possible to measure several quantitative properties of the PPIs. For example, to identify the exact amino acids of crosslink, the topology of the interaction, the levels of interaction partners in the PPI, the abundance and orientation of the interaction (Chavez et al. 2011).

Likewise, chemical-crosslink label transfer incorporates the crosslinking methodology to study PPIs in vitro by labeled proteins (Fig. 5). The method uses a bifunctional, cleavable cross-linking agent which contains detectable tag (biotin, radiolabel, fluorescent). This crosslinker is first conjugated to bait protein, which is then used for studying interaction with prey. After the interaction of the modified bait with its prey, the cross-linking agent is activated to crosslink bait and prey proteins. Then the complex is cleaved in such a manner that the detectable tag is transferred from the bait to prey protein. The resulting modified prey is analyzed by Western blot, MS, or by protein sequencing (Chen et al. 1994; Fancy 2000; Lam et al. 2002).

SPINE combines the advantages of the reversible crosslinking procedure by formaldehyde and specific purification of proteins by Strep-tag affinity chromatography. It works in a such way that the bait protein is engineered as a fusion protein with a strep-tag. After crosslinking, the protein complexes are purified by affinity chromatography using immobilized streptavidin or strep-tactin. Isolated complexes are subsequently eluted by biotin or desthiobiotin. Then crosslinks are reversed and the fractions of proteins are analyzed by immunoblotting (Herzberg et al. 2007).

\section{Affinity capillary electrophoresis (ACE)}

ACE is based on the principle of capillary electrophoresis with few modifications (Virtanen 1974), which was first reported in the early 90 s for the study of binding constants. ACE is a quantitative method that is based on the changes of electrophoretic mobility patterns of the studied protein upon interaction with other proteins or ligands (Chu et al. 1992). Besides PPIs, it is possible to also study interactions of proteins with other ligands, for example, with drugs (Hail and Lee 1998), metal ions (Redweik et al. 2013), nucleic acids (Malonga et al. 2006), and other molecules. ACE allows measuring binding constants (Chu et al. 1992; Avila et al. 1993), the charge of the formed complex (Colton et al. 1998), and the binding stoichiometry.

\section{Display technologies}

Display technologies are mainly used for the identification of ligands of bait protein from libraries of peptides or proteins. Among them, the most popular are phage display (Smith 1985), the ribosome display (RD) (Hanes 
A

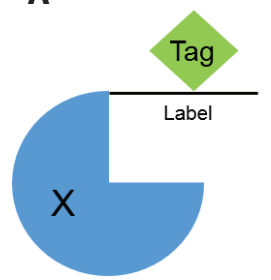

B

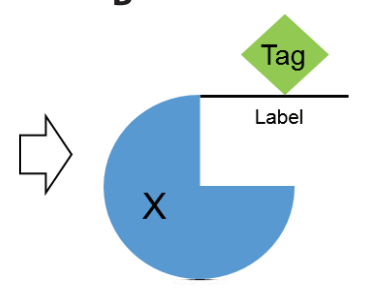

C

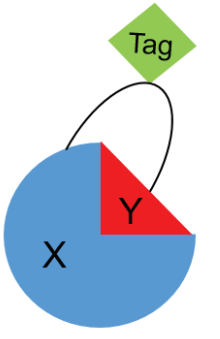

D

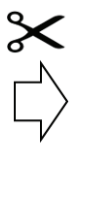

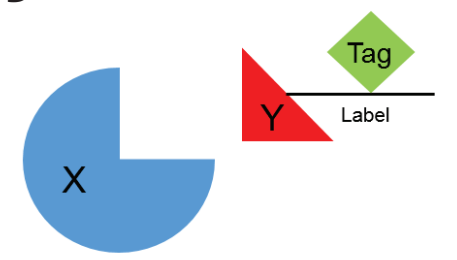

Figure 5. Label transfer. A. The bait protein is conjugated with a bifunctional, cleavable cross-linking agent which contains a detectable tag (label). B. Modified bait is incubated with its prey. After their interaction, proteins are crosslinked (C), the cross-linker is cleaved, whereby the tag is transferred to the prey protein $(\mathrm{D})$. X, bait protein; $\mathrm{Y}$, prey protein.

and Plückthun 1997), and the mRNA display (Roberts and Szostak 1997). All display technologies possess the common feature that each protein molecule (phenotype) is linked with its encoding sequence (genotype). The bait protein is immobilized on a solid surface, and a library of potential prey-gene complexes are applied to immobilized bait. After washing, bound prey complexes are eluted, amplified, and analyzed by DNA sequencing. The link between phenotype and genotype, is maintained by phages themselves in phage-display (Smith 1985), by mRNA-ribosome-protein complexes in ribosome display (Hanes and Plückthun 1997), and by mRNA-protein molecules in mRNA display (Roberts and Szostak 1997).

Phage display utilizes bacteriophages to noncovalently couple a protein displayed on the phage surface with its DNA encoding sequence, which is inserted into one of the phage coat protein genes. Phage libraries displaying peptides or proteins (as big as $10^{11}$ ) are used for the screening and selection against immobilized bait protein. After washing, bound phages are eluted, amplified in bacteria, and used for the further round of selection (Smith 1985). After several rounds of enrichment, single phages are amplified and their DNA is sequenced (Fig. 6). The phage display enables qualitative screening of interaction partners of proteins of interest. It can be divided into two groups: the combinatorial peptide phage display and the proteomic phage display. The combinatorial peptide phage display relies on highly diverse libraries to identify high-affinity short peptide ligands (Noren and Noren 2001). The proteomic phage display is used for the display of a target proteome, for example, scFv antibody fragments, cDNAs, ORFs, expression products from genomic DNA, or proteins from a designed synthetic oligonucleotide library. Over time several modifications of phage display have been developed. For detailed information, we refer the readers to the dedicated review (Sundell and Ivarsson 2014).

Ribosome display (RD), is a completely in vitro method which links the proteins of interest with their mRNA through a stalled ribosome-mRNA-protein complex. RD is performed using cell-free translational systems from bacteria (Hanes and Plückthun 1997), wheat germ (Roberts and Paterson 1973), yeasts (Gasior et al. 1979; Tuite et al. 1980) or rabbit reticulocytes (Pelham and Jackson 1976). RD is heavily dependent on the integrity of the ribosome-mRNA-protein complexes. With RD, it is possible to screen large synthetic and natural proteome libraries with high diversities $\left(>10^{12}\right)$ (Hanes and Plückthun 1997). During the ribosome display, procedure library of identified proteins could be evolved, and binding properties could be improved which can help identify critical amino acids for the interaction.

The mRNA display is also a completely in vitro method with many similarities to RD (Roberts and Szostak 1997). Before screening the mRNA library is first modified with puromycin at the $3{ }^{\prime}$-end. During translation, mRNA molecules are covalently linked to synthesized polypeptides. Since the mRNA and polypeptide are covalently linked, complexes are more stable. After several rounds of selection, mRNA is reverse transcribed, amplified by PCR, cloned, and amino acid sequences or selected proteins are revealed by DNA sequencing.

\section{Isothermal titration calorimetry (ITC)}

ITC (Wiseman et al. 1989) is currently the only method for the quantitative measurement of isothermal changes (thermodynamic parameters) upon protein binding by a simple titration. It is possible to determine the stoichiometry, enthalpy, entropy, Gibbs free energy and binding constants of the interaction. ITC measures the binding equilibrium of a ligand with its binding partner by determining the release or uptake of heat upon their association in the solution (Pierce et al. 1999). The basic experimental setup includes a sample cell and a reference cell placed in an adiabatic jacket. The sample cell contains the protein of interest, while the reference cell contains the buffer in which the sample is dissolved. Subsequently, the protein of interest is titrated with its interaction partner, resulting in uptake or release of heat. Temperature-sensitive circuits are used to detect thermal 


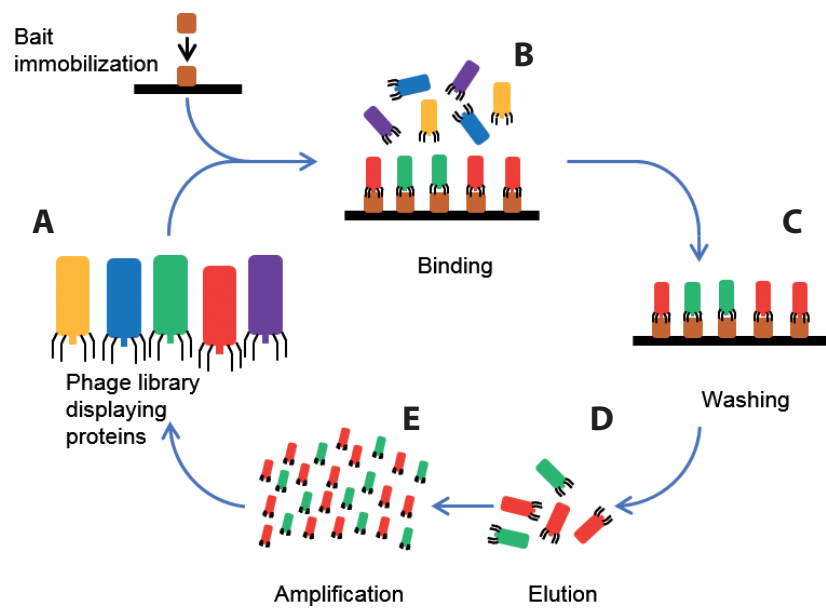

Figure 6. Phage display. A. The first step in phage display is the creation of a phage library, where a library of peptides or proteins is displayed on the phage surface as a fusion with one of its coat proteins. B. The library is used for screening against immobilized bait protein (brown). After washing, only phages interacting with bait are retained (C). Eluted phages (D) are amplified (E) and used either for the next round of selection or proteins can be identified by sequencing of phage DNA. This cycle can be repeated several times.

differences between the reference and sample cell, which are subsequently analyzed (Pierce et al. 1999).

\section{Surface plasmon resonance (SPR)}

SPR (Liedberg et al. 1983), is an optical real-time quantitative method used for the measurement of PPIs: kinetics, rate of association and dissociation, affinity, stoichiometry and concentration. The SPR is based on the detection of refractive index changes that occur after the binding between the prey in solution and bait immobilized on the sensor chip surface (Rich and Myszka 2000). When monochromatic polarized light is reflected from a metal-coated interface (usually gold), the intensity of this reflected light is reduced at a specific incident angle, which is termed the SPR angle (Fig. 7) (Nguyen et al. 2007). As the proteins interact, a change in the mass concentration at the metal surface occurs, which alters the refractive index and SPR angle at which polarized light is reflected. During the dissociation of the analyte, an inverse phenomenon is observed which allows the determination of the kinetic constants (Nguyen et al. 2015).

\section{Backscattering interferometry (BSI) and bio-layer interfer- ometry (BLI)}

BSI (Bornhop 1995) is a quantitative method measuring binding affinities of two interacting partners, which similar to SPR, measures the changes in the refractive index, usually in a nanoscale (Swinney et al. 2000), resulting from the interaction of two proteins either immobilized or in a solution. It is based on the study of the backscattered interference pattern which is generated by a laser light that illuminates the microfluidic channel containing the protein interaction partners (Markov et al. 2004; Bornhop et al. 2007; Baksh et al. 2011).

BLI is a real-time, label-free optical bioanalytical method based on the reflective property of white light that can be used to detect PPIs, and to quantitively measure several of their properties, like association, dissociation (binding kinetics), affinity and concentrations of proteins. In BLI, one protein is immobilized on the biosensor tip and the second protein is free in solution. If white light is applied to the biosensor tip, it is reflected back from two surfaces: immobilized protein on the biosensor tip surface and the reference surface. Light waves, which propagate back, interact and create an interference pattern. Some wavelengths show constructive interference, others destructive interference. If the immobilized protein on the biosensor tip surface interacts with the protein in solution, the shift in the interference pattern occurs. This interference is captured by a spectrometer across the entire white light spectrum (Concepcion et al. 2009).

\section{Circular dichroism (CD)}

CD (Greenfield and Fasman 1969) is built on changes in the spin angular momentum resulting from the differential absorption of left- and right-handed circularly polarized light, depending on the conformation of proteins i.e. dextrorotary or levorotary characteristics. The interaction of proteins does affect their conformation, thus shifting their $\mathrm{CD}$ spectrum. This can be examined at various concentrations of binding partners and at different time points, which provides information about the binding constants (Woody 1995; Greenfield 2004).

\section{Dual polarization interferometry (DPI)}

DPI (Cross et al. 1999; Cross et al. 2003) is a label-free optical method that provides a real-time multiparametric measurement of molecules, able to monitor molecular dimension, packing (layer refractive index and density), and gives information about stoichiometry and dissociation constant (Swann et al. 2004). The principle of the dual-polarization interferometry is the change in the refractive index and layer thickness above the waveguide surface, where bait and prey interaction occur, which alter the velocity of propagation of the light, in the sensing waveguide, resulting in a change of the phase position of the interference fringes dependent on protein interaction (Fig. 8) (Escorihuela et al. 2015). 
A

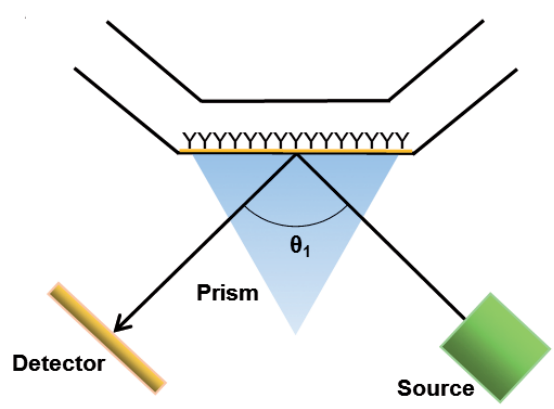

B

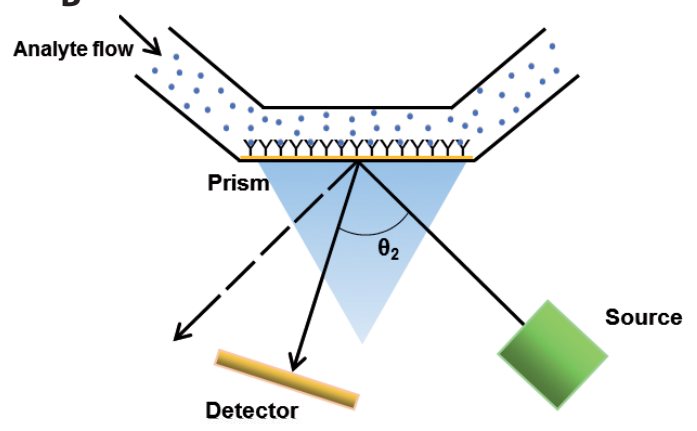

Figure 7. Surface plasmon resonance. A. The bait protein is immobilized on the metal surface layer. Applied polarized light is reflected under a specific angle (SPR angle; $\theta 1)$. B. If the prey interacts with bait and creates complex, the refractive index near the surface changes what results in a change of SPR angle of reflected polarized light $(\theta 2)$.

Atomic force microscopy (AFM)

AFM is an in vitro method used to quantitatively measure the strength between two interacting ligands. It is based on the scan of a surface with a probe attached to a cantilever at a set distance or force (Binnig et al. 1986). The movements of the flexible cantilever can be monitored by changes in laser deflection of a reflective surface on the backside of the cantilever. After the proteins of interest are attached, one to the surface and the other to the cantilever, the interaction between them can be measured to characterize the strength of the binding (Lin et al. 2005).

$X$-ray crystallography (XRC) and nuclear magnetic resonance $(N M R)$

XRC and NMR are the oldest analytical methods focusing on resolving the structure of proteins and protein complexes. The availability of the protein structure of an unknown protein provides several useful information. The data from the XRC is a three-dimensional molecular structure from a protein crystal. The method uses the exposure of a highly purified, concentrated and crystallized sample to X-ray beams and determining the structure by the analysis of diffraction patterns (Blundell et al. 1976).
Although X-ray crystallography provides information about the structure of a single protein or protein complexes, it is overshadowed by other methods to study of PPIs because of the requirement of a purified crystal sample (Kobe et al. 2008).

NMR is an established biophysical method for the study of intermolecular interactions. NMR can determine structures of large subunits and their complexes (Zuiderweg 2002; O'Connell et al. 2009). The principle of NMR is based on three stages: the nuclear spins in a magnetic field, the perturbation of this polarization by a weak oscillating magnetic field, and the detection of the electromagnetic waves emitted by the nuclei. The structure of the PPIs can be studied by several NMR methods, for example, chemical shift perturbation mapping. In this method, the ${ }^{15} \mathrm{~N}-{ }^{1} \mathrm{H}$ heteronuclear single quantum coherence spectrum of $\mathrm{a}^{15} \mathrm{~N}$-labelled molecule allows following shifts of the amino acid resonance upon addition of an unlabelled partner, which can help to identify and localize the binding sites (Cala et al. 2014). Another NMR method used for the study of PPIs uses the Nuclear Overhauser effect to measure the distance between two protons, which takes advantage of the spatial information for the identification of interaction (Kaiser 1963; Cala et al. 2014).
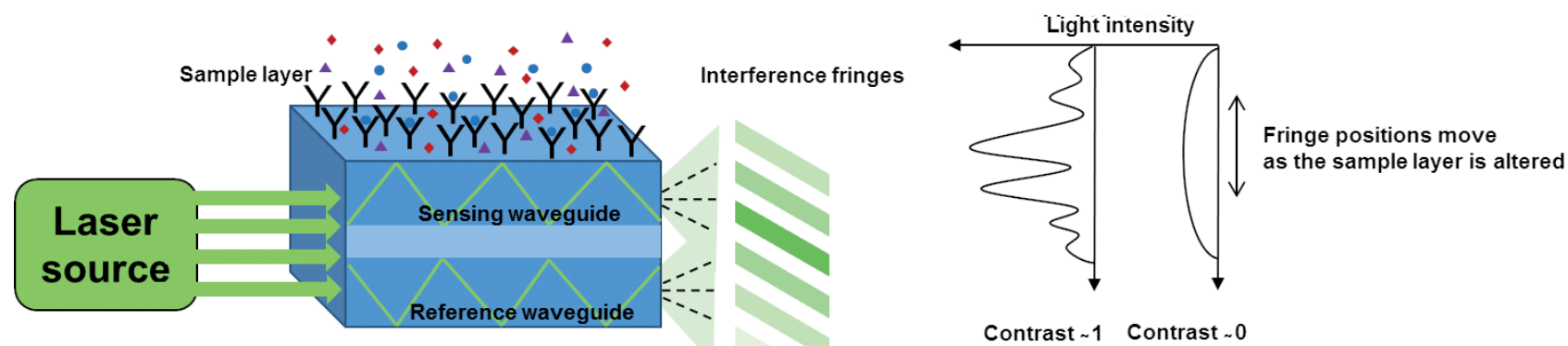

Figure 8. Dual polarization interferometry. The light from the laser source is split into referential and sensing waveguides. The sensing waveguide contains a layer with bound bait protein, with its given refractive index (RI). The velocity of the light from the sensing waveguide is impacted by RI and thus influences the distribution of the interference fringes, which are created at the end of the waveguides. The binding of the bait protein with its prey will result in the change of the RI of the sample layer, thus changing the velocity and distribution of interference fringes. 
Fluorescence polarization (FP)

FP (Perrin 1926; Weber 1952, 1960) or anisotropy spectroscopy, is a fluorescent method used for the quantitative study of interactions in solutions, where one of the reactants is relatively smaller (usually $<1500 \mathrm{Da}$ ), compared to its interaction partner $(>10 \mathrm{kDa})$. Smaller interaction partner must be fluorescent or labeled with a fluorophore. The FP is based on the quantification of the changes in fluorescence polarization of a fluorophore attached to the protein of interest, while it undergoes rotational or translational movements during excitation. The degree of the emitted polarized light from the excited molecule is inversely proportional to the rate of molecular rotation (Fig. 9) (Du 2015). Unequal emission intensities are obtained along different axes of polarization that depend directly on the size of the fluorophore, which reveals information on specific PPIs. With fluorescence polarization, it is possible to measure dissociation constants of the interaction. Using FP it is also possible to identify new inhibitors for enzyme (reviewed in (Hall et al. 2016)).

\section{Microscale thermophoresis (MST)}

MST is a method used for quantitative analysis of interactions in a microliter scale and near-native conditions (biological liquids, lysate, blood plasma), and is based on the thermophoresis phenomenon which is the directed flow of molecules in a temperature gradient in a solution (Ludwig 1856). Any variation of the chemical microenvironment of the fluorescent molecule results in a relative change of the fluorescence detected when a temperature gradient is applied

A
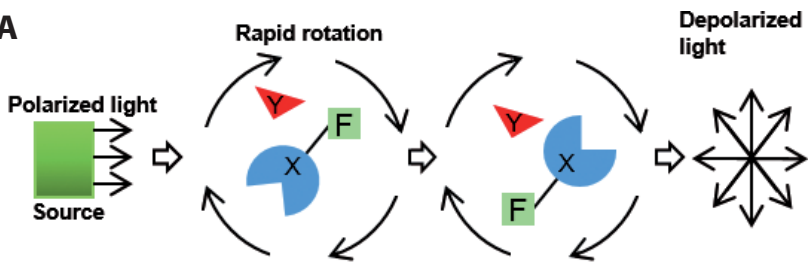

$\mathrm{B}$
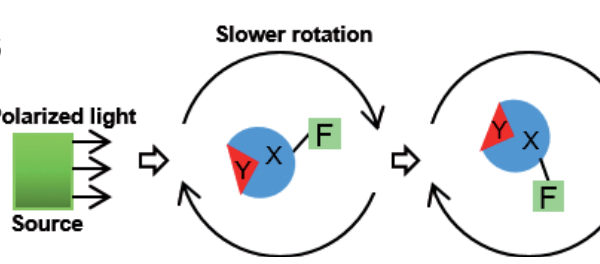

Largely

polarized light
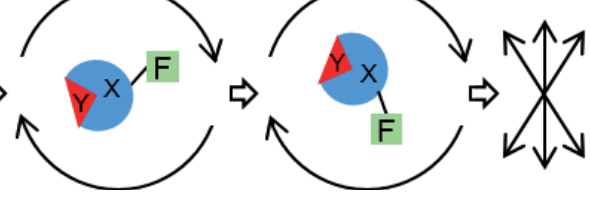

Figure 9. Fluorescence polarization. The bait protein $(\mathrm{X})$ is fused to a fluorophore (F), which undergoes rotational movements while being excited. A. The bait protein is not interacting with the prey (Y) therefore the excited fluorophore rotates rapidly and its emitted light is largely depolarized. B. The bait protein is interacting with the prey protein, which results into a slower rotation of the excited fluorophore and increased polarized light.
(Jerabek-Willemsen et al. 2014; Mao et al. 2015). MST is based on two effects: a) temperature-related alteration of the fluorescence of the molecule which depends on its charge, size and hydration shell, and b) a change in its motion along the microscopic temperature gradient. MST provides information about enzyme kinetics, dissociation and association constants, stoichiometry, enthalpy, entropy and Gibbs free energy. It measures interactions with essentially no limitation on molecule size or molecular weight.

\section{In silico methods}

In recent years, the attention has been drawn closer to the study of interaction networks because properties of complex systems seem to be more determined by the protein-protein interactions, than by the characteristics of their single components. The study of interaction networks could lead to the prediction of new PPIs, and development of new drugs which could modulate or interrupt PPIs in disease conditions. Along with the progress in computer sciences, many in silico methods have been developed for the prediction of novel PPIs using proteomes from various organisms (Huynen et al. 2000). Many network databases of validated or predicted protein-protein associations and interactions have been created, for example, STRING (Szklarczyk et al. 2019), DIP (Xenarios et al. 2002), PrePPI (Zhang et al. 2012) and the BioGRID (Stark et al. 2006; Oughtred et al. 2019). Several tools e. g. Cytoscape (Su et al. 2014), HIPPIE (AlanisLobato et al. 2016), PINOT (Im et al. 2018), MIST (Arkian et al. 2017) are accessible which process the data from these databases, and facilitate the creation of PPI networks and allow subsequent analysis.

The in silico methods can be divided into three groups according to their approach: 1) methods utilizing sequencebased approaches, 2) methods utilizing structure-based approaches, and 3) the network analysis methods (Wu et al. 2009). Currently, the most used methods for the prediction of PPIs are ortholog-based sequence approach (Lee et al. 2008), domain-pairs-based sequence approach (Wojcik and Schächter 2001; Memišević et al. 2013), in silico two-hybrid system (Pazos and Valencia 2002), gene neighborhood (Dandekar et al. 1998), gene fusion (Enright et al. 1999; Tsoka and Ouzounis 2000) and phylogenetic tree (Fryxell 1996; Goh et al. 2000; Pazos and Valencia 2001). For detailed information about currently used in silico methods, we recommend the readers to a detailed review (Shatnawi 2015).

In silico methods are based on either statistical assumptions or machine learning, and are applied to protein sequences, structures or whole databases. Several in silico methods can predict potential PPIs with high probability mainly those which are based on ortholog-based sequence approach or domain-pairs-based sequence approach. Be- 
cause results obtained by in silico methods are mainly predictions it is in many cases necessary to prove those potential PPIs by "wet lab" methods.

\section{Conclusions}

Proteins are fundamental components of each organism where they play various important roles. Many processes in living organisms are based on the interactions between two or more proteins. The discovery and study of the PPIs has lead to better understanding of the basic processes occurring in the organisms, which, when interrupted or altered, can be detrimental. After the discovery of the importance of proteins and their interactions, many novel methods to study PPIs have been developed. The methods can be divided into three different groups depending on the environment used in vivo, in vitro, and in silico. They can be applied for qualitative and/or quantitative characterization of PPIs. Currently, the most preferred methods for the study of PPIs are the $\mathrm{Y} 2 \mathrm{H}, \mathrm{co}$-immunoprecipitation and affinity chromatography, FRET, XL-MS, ITC and SPR. Many of the methods and their modifications do have their advantages and disadvantages, which have to be considered according to the requirements for the interactions studied.

\section{References}

Akerström B, Brodin T, Reis K, Björck L (1985): Protein G: a powerful tool for binding and detection of monoclonal and polyclonal antibodies. J. Immunol. 135, 2589-2592

Alanis-Lobato G, Andrade-Navarro MA, Schaefer MH (2016): HIPPIE v2. 0: enhancing meaningfulness and reliability of protein-protein interaction networks. Nucleic Acids Res. 45, D408-D414 https://doi.org/10.1093/nar/gkw985

Antonia SJ, Villegas A, Daniel D, Vicente D, Murakami S, Hui R, Yokoi T, Chiappori A, Lee KH, de Wit M (2017): Durvalumab after chemoradiotherapy in stage III non-small-cell lung cancer. N. Engl. J. Med. 377, 1919-1929 https://doi.org/10.1056/NEJMoa1709937

Arkian HR, Diyanat A, Pourkhalili A (2017): MIST: Fog-based data analytics scheme with cost-efficient resource provisioning for IoT crowdsensing applications. J. Netw. Comput. Appl. 82, $152-165$ https://doi.org/10.1016/j.jnca.2017.01.012

Aronheim A, Zandi E, Hennemann H, Elledge SJ, Karin M (1997): Isolation of an AP-1 repressor by a novel method for detecting protein-protein interactions. Mol. Cell. Biol. 17, 3094-3102 https://doi.org/10.1128/MCB.17.6.3094

Atmakuri K, Ding Z, Christie PJ (2003): VirE2, a type IV secretion substrate, interacts with the VirD4 transfer protein at cell poles of Agrobacterium tumefaciens. Mol. Microbiol. 49, 1699-1713

https://doi.org/10.1046/j.1365-2958.2003.03669.x
Avila LZ, Chu YH, Blossey EC, Whitesides GM (1993): Use of affinity capillary electrophoresis to determine kinetic and equilibrium constants for binding of arylsulfonamides to bovine carbonic anhydrase. J. Med. Chem. 36, 126-133 https://doi.org/10.1021/jm00053a016

Bacia K, Kim SA, Schwille P (2006): Fluorescence cross-correlation spectroscopy in living cells. Nat. Methods 3, 83-89 https://doi.org/10.1038/nmeth822

Bader AN, Hofman EG, Voortman J, en Henegouwen PM, Gerritsen HC (2009): Homo-FRET imaging enables quantification of protein cluster sizes with subcellular resolution. Biophys. J. 97, 2613-2622 https://doi.org/10.1016/j.bpj.2009.07.059

Baksh MM, Kussrow AK, Mileni M, Finn M, Bornhop DJ (2011): Label-free quantification of membrane-ligand interactions using backscattering interferometry. Nat. Biotechnol. 29, 357-360 https://doi.org/10.1038/nbt.1790

Barnard E, McFerran Neil V, Trudgett A, Nelson J, Timson David J (2008): Development and implementation of split-GFP-based bimolecular fluorescence complementation (BiFC) assays in yeast. Biochem. Soc. Trans. 36, 479-482 https://doi.org/10.1042/BST0360479

Barrios-Rodiles M, Brown KR, Ozdamar B, Bose R, Liu Z, Donovan RS, Shinjo F, Liu Y, Dembowy J, Taylor IW, et al. (2005): High-throughput mapping of a dynamic signaling network in mammalian cells. Science 307, 1621-1625 https://doi.org/10.1126/science.1105776

Bickle TA, Hershey JW, Traut RR (1972): Spatial arrangement of ribosomal proteins: reaction of the Escherichia coli 30 S subunit with bis-imidoesters. Proc. Natl. Acad. Sci. USA 69, 1327-1331 https://doi.org/10.1073/pnas.69.5.1327

Binnig G, Quate CF, Gerber C (1986): Atomic force microscope. Phys. Rev. Lett. 56, 930-933 https://doi.org/10.1103/PhysRevLett.56.930

Bjorke H, Andersson K (2006): Measuring the affinity of a radioligand with its receptor using a rotating cell dish with in situ reference area. Appl. Radiat. Isot. 64, 32-37 https://doi.org/10.1016/j.apradiso.2005.06.007

Blundell TL, Johnson L, Johnson LN (1976): Protein Crystallography. Academic Press, New York, USA

Bochar DA, Wang L, Beniya H, Kinev A, Xue Y, Lane WS, Wang W, Kashanchi F, Shiekhattar R (2000): BRCA1 is associated with a human SWI/SNF-related complex: linking chromatin remodeling to breast cancer. Cell 102, 257-265 https://doi.org/10.1016/S0092-8674(00)00030-1

Bongrand P (1999): Ligand-receptor interactions. Rep. Prog. Phys. 62, 921 https://doi.org/10.1088/0034-4885/62/6/202

Borghaei H, Paz-Ares L, Horn L, Spigel DR, Steins M, Ready NE, Chow LQ, Vokes EE, Felip E, Holgado E (2015): Nivolumab versus docetaxel in advanced nonsquamous non-small-cell lung cancer. N. Engl. J. Med. 373, 1627-1639 https://doi.org/10.1056/NEJMoa1507643

Bornhop DJ (1995): Microvolume index of refraction determinations by interferometric backscatter. Appl. Opt. 34, 3234-3239 https://doi.org/10.1364/AO.34.003234

Bornhop DJ, Latham JC, Kussrow A, Markov DA, Jones RD, Sørensen HS (2007): Free-solution, label-free molecular interac- 
tions studied by back-scattering interferometry. Science 317, $1732-1736$

https://doi.org/10.1126/science.1146559

Boyerinas B, Jochems C, Fantini M, Heery CR, Gulley JL, Tsang KY, Schlom J (2015): Antibody-dependent cellular cytotoxicity activity of a novel anti-PD-L1 antibody avelumab (MSB0010718C) on human tumor cells. Cancer Immunol. Res. 3, 1148-1157 https://doi.org/10.1158/2326-6066.CIR-15-0059

Bracha-Drori K, Shichrur K, Katz A, Oliva M, Angelovici R, Yalovsky S, Ohad N (2004): Detection of protein-protein interactions in plants using bimolecular fluorescence complementation. Plant J. 40, 419-427 https://doi.org/10.1111/j.1365-313X.2004.02206.x

Broder YC, Katz S, Aronheim A (1998): The ras recruitment system, a novel approach to the study of protein-protein interactions. Curr. Biol. 8, 1121-1124 https://doi.org/10.1016/S0960-9822(98)70467-1

Cala O, Guillière F, Krimm I (2014): NMR-based analysis of proteinligand interactions. Anal. Bioanal. Chem. 406, 943-956 https://doi.org/10.1007/s00216-013-6931-0

Chavez JD, Liu NL, Bruce JE (2011): Quantification of proteinprotein interactions with chemical cross-linking and mass spectrometry. J. Proteome Res. 10, 1528-1537 https://doi.org/10.1021/pr100898e

Chen Y, Ebright YW, Ebright RH (1994): Identification of the target of a transcription activator protein by protein-protein photocrosslinking. Science 265, 90-92 https://doi.org/10.1126/science.8016656

Chen Y, Periasamy A (2004): Characterization of two-photon excitation fluorescence lifetime imaging microscopy for protein localization. Microsc. Res. Tech. 63, 72-80 https://doi.org/10.1002/jemt.10430

Chijiwa T, Hagiwara M, Hidaka H (1989): A newly synthesized selective casein kinase I inhibitor, $\mathrm{N}$-(2-aminoethyl)5-chloroisoquinoline-8-sulfonamide, and affinity purification of casein kinase I from bovine testis. J. Biol. Chem. 264, 4924-4927 https://doi.org/10.1016/S0021-9258(18)83679-1

Choi JH, Lee JA, Yim SW, Lim CS, Lee CH, Lee YD, Bartsch D, Kandel ER, Kaang BK (2003): Using an Aplysia two-hybrid system to examine the interactions between transcription factors involved in long-term facilitation in the nervous system of Aplysia. Learn. Mem. 10, 40-43 https://doi.org/10.1101/lm.55303

Chu YH, Avila LZ, Biebuyck HA, Whitesides GM (1992): Use of affinity capillary electrophoresis to measure binding constants of ligands to proteins. J. Med. Chem. 35, 2915-2917 https://doi.org/10.1021/jm00093a027

Collins FS, Morgan M, Patrinos A (2003): The Human Genome Project: lessons from large-scale biology. Science 300, 286-290 https://doi.org/10.1126/science.1084564

Collins MO, Choudhary JS (2008): Mapping multiprotein complexes by affinity purification and mass spectrometry. Curr. Opin. Biotechnol. 19, 324-330 https://doi.org/10.1016/j.copbio.2008.06.002

Colton IJ, Carbeck JD, Rao J, Whitesides GM (1998): Affinity capillary electrophoresis: A physical-organic tool for studying interactions in biomolecular recognition. Electrophoresis 19, 367-382

https://doi.org/10.1002/elps.1150190303

Concepcion J, Witte K, Wartchow C, Choo S, Yao D, Persson H, Wei J, Li P, Heidecker B, Ma W (2009): Label-free detection of biomolecular interactions using BioLayer interferometry for kinetic characterization. Comb. Chem. High Throughput Screen 12, 791-800 https://doi.org/10.2174/138620709789104915

Cori GT, Cori CF (1945): The enzymatic conversion of phosphorylase a to b. J. Biol. Chem. 158, 321-332 https://doi.org/10.1016/S0021-9258(18)43139-0

Cross GH, Reeves AA, Brand S, Popplewell JF, Peel LL, Swann MJ, Freeman NJ (2003): A new quantitative optical biosensor for protein characterisation. Biosens. Bioelectron. 19, 383-390 https://doi.org/10.1016/S0956-5663(03)00203-3

Cross GH, Ren Y, Freeman NJ (1999): Young's fringes from vertically integrated slab waveguides: applications to humidity sensing. J. Appl. Phys. 86, 6483-6488 https://doi.org/10.1063/1.371712

Cuatrecasas P, Wilchek M, Anfinsen CB (1968): Selective enzyme purification by affinity chromatography. Proc. Natl. Acad. Sci. USA 61, 636 https://doi.org/10.1073/pnas.61.2.636

Cull MG, Miller JF, Schatz PJ (1992): Screening for receptor ligands using large libraries of peptides linked to the $C$ terminus of the lac repressor. Proc. Natl. Acad. Sci. USA 89, 1865-1869 https://doi.org/10.1073/pnas.89.5.1865

Daines DA, Granger-Schnarr M, Dimitrova M, Silver RP (2002): Use of LexA-based system to identify protein-protein interactions in vivo. In: Methods Enzymol. (Eds. LC Virginia, PM Bavoil), pp 153-161, Academic Press, New York, NY, USA https://doi.org/10.1016/S0076-6879(02)58087-3

Dandekar T, Snel B, Huynen M, Bork P (1998): Conservation of gene order: a fingerprint of proteins that physically interact. Trends Biochem. Sci. 23, 324-328 https://doi.org/10.1016/S0968-0004(98)01274-2

Dawes ML, Soeller C, Scholpp S (2020): Studying molecular interactions in the intact organism: fluorescence correlation spectroscopy in the living zebrafish embryo. Histochem. Cell Biol. 154, 507-519 https://doi.org/10.1007/s00418-020-01930-5

De Jong LA, Uges DR, Franke JP, Bischoff R (2005): Receptor-ligand binding assays: technologies and applications. J. Chromatogr. B Analyt. Technol. Biomed. Life Sci. 829, 1-25 https://doi.org/10.1016/j.jchromb.2005.10.002

Defeu Soufo HJ, Graumann PL (2006): Dynamic localization and interaction with other Bacillus subtilis actin-like proteins are important for the function of MreB. Mol. Microbiol. 62, 1340-1356 https://doi.org/10.1111/j.1365-2958.2006.05457.x

Dimri S, Basu S, De A (2016): Use of BRET to Study Protein-Protein Interactions In Vitro and In Vivo. In: Methods Mol. Biol. (Ed. IJ McEwan), pp 57-78, Humana Press, New York, NY, USA https://doi.org/10.1007/978-1-4939-3724-0_5

Dmitrova M, Younes-Cauet G, Oertel-Buchheit P, Porte D, Schnarr M, Granger-Schnarr M (1998): A new LexA-based genetic sys- 
tem for monitoring and analyzing protein heterodimerization in Escherichia coli. Mol. Gen. Genet. 257, 205-212 https://doi.org/10.1007/s004380050640

Dodd IB, Perkins AJ, Tsemitsidis D, Egan JB (2001): Octamerization of $\lambda \mathrm{CI}$ repressor is needed for effective repression of $\mathrm{P}$ $\mathrm{RM}$ and efficient switching from lysogeny. Genes Dev. 15, 3013-3022 https://doi.org/10.1101/gad.937301

Dorr P, Westby M, Dobbs S, Griffin P, Irvine B, Macartney M, Mori J, Rickett G, Smith-Burchnell C, Napier C (2005): Maraviroc (UK-427,857), a potent, orally bioavailable, and selective smallmolecule inhibitor of chemokine receptor CCR5 with broadspectrum anti-human immunodeficiency virus type 1 activity. Antimicrob. Agents Chemother. 49, 4721-4732 https://doi.org/10.1128/AAC.49.11.4721-4732.2005

Dos Remedios CG, Moens PD (1995): Fluorescence resonance energy transfer spectroscopy is a reliable" ruler" for measuring structural changes in proteins: dispelling the problem of the unknown orientation factor. J. Struct. Biol. 115, 175-185 https://doi.org/10.1006/jsbi.1995.1042

Du Y (2015): Fluorescence polarization assay to quantify proteinprotein interactions in an HTS format. In: Protein-Protein Interactions (Eds. CL Meyerkord, F Haian), pp 529-544, Springer Science+Business Media, New York, NY, USA https://doi.org/10.1007/978-1-4939-2425-7_35

Duckworth WC, Heinemann MA, Kitabchi AE (1972): Purification of insulin-specific protease by affinity chromatography. Proc. Natl. Acad. Sci. USA 69, 3698-3702 https://doi.org/10.1073/pnas.69.12.3698

Ehlert A, Weltmeier F, Wang X, Mayer CS, Smeekens S, VicenteCarbajosa J, Droge-Laser W (2006): Two-hybrid proteinprotein interaction analysis in Arabidopsis protoplasts: establishment of a heterodimerization map of group $\mathrm{C}$ and group $\mathrm{S}$ bZIP transcription factors. Plant J. 46, 890-900 https://doi.org/10.1111/j.1365-313X.2006.02731.x

Ehrhard KN, Jacoby JJ, Fu XY, Jahn R, Dohlman HG (2000): Use of G-protein fusions to monitor integral membrane proteinprotein interactions in yeast. Nat. Biotechnol. 18, 1075-1079 https://doi.org/10.1038/80274

Ehrlich P (1891a): Experimentelle untersuchungen über immunität. I. Ueber ricin. Dtsch. Med. Wochenschr. 17, 976-979 https://doi.org/10.1055/s-0029-1206682

Ehrlich P (1891b): Experimentelle untersuchungen über immunität. II. Ueber abrin. Dtsch. Med. Wochenschr. 17, 1218-1219 https://doi.org/10.1055/s-0029-1206825

Eigen M, Rigler R (1994): Sorting single molecules: application to diagnostics and evolutionary biotechnology. Proc. Natl. Acad. Sci. USA 91, 5740-5747 https://doi.org/10.1073/pnas.91.13.5740

Elangovan M, Day R, Periasamy A (2002): Nanosecond fluorescence resonance energy transfer-fluorescence lifetime imaging microscopy to localize the protein interactions in a single living cell. J. Microsc. 205, 3-14 https://doi.org/10.1046/j.0022-2720.2001.00984.x

Elson EL, Magde D (1974): Fluorescence correlation spectroscopy. I. Conceptual basis and theory. Biopolymers 13, 1-27 https://doi.org/10.1002/bip.1974.360130102
Elvekrog MM, Gonzalez Jr. RL (2013): Conformational selection of translation initiation factor 3 signals proper substrate selection. Nat. Struct. Mol. Biol. 20, 628

https://doi.org/10.1038/nsmb.2554

Embree LJ, Azuma M, Hickstein DD (2009): Ewing sarcoma fusion protein EWSR1/FLI1 interacts with EWSR1 leading to mitotic defects in zebrafish embryos and human cell lines. Cancer Res. 69, 4363-4371 https://doi.org/10.1158/0008-5472.CAN-08-3229

Enright AJ, Iliopoulos I, Kyrpides NC, Ouzounis CA (1999): Protein interaction maps for complete genomes based on gene fusion events. Nature 402, 86-90 https://doi.org/10.1038/47056

Escorihuela J, González-Martínez MA, López-Paz JL, Puchades R, Maquieira A, Gimenez-Romero D (2015): Dual-polarization interferometry: a novel technique to light up the nanomolecular world. Chem. Rev. 115, 265-294 https://doi.org/10.1021/cr5002063

Eyckerman S, Verhee A, der Heyden JV, Lemmens I, Ostade XV, Vandekerckhove J, Tavernier J (2001): Design and application of a cytokine-receptor-based interaction trap. Nat. Cell Biol. 3, 1114-1119

https://doi.org/10.1038/ncb1201-1114

Fancy DA, Kodadek T (1999): Chemistry for the analysis of protein-protein interactions: rapid and efficient cross-linking triggered by long wavelength light. Proc. Natl. Acad. Sci. USA 96, 6020-6024 https://doi.org/10.1073/pnas.96.11.6020

Fancy DA (2000): Elucidation of protein-protein interactions using chemical cross-linking or label transfer techniques. Curr. Opin. Chem. Biol. 4, 28-33

https://doi.org/10.1016/S1367-5931(99)00047-2

Fenn JB, Mann M, Meng CK, Wong SF, Whitehouse CM (1989): Electrospray ionization for mass spectrometry of large biomolecules. Science 246, 64-71 https://doi.org/10.1126/science.2675315

Fields S, Song O (1989): A novel genetic system to detect proteinprotein interactions. Nature 340, 245-246 https://doi.org/10.1038/340245a0

Fleischmann RD, Adams MD, White O, Clayton RA, Kirkness EF, Kerlavage AR, Bult CJ, Tomb JF, Dougherty BA, Merrick JM, et al. (1995): Whole-genome random sequencing and assembly of Haemophilus influenzae Rd. Science 269, 496-512

https://doi.org/10.1126/science.7542800

Förster T (1948): Zwischenmolekulare energiewanderung und fluoreszenz. Annalen der Physik (Leipzig) 437, 55-75 (in German) https://doi.org/10.1002/andp.19484370105

Fredriksson S, Gullberg M, Jarvius J, Olsson C, Pietras K, Gústafsdóttir SM, Östman A, Landegren U (2002): Protein detection using proximity-dependent DNA ligation assays. Nat. Biotechnol. 20, 473-477 https://doi.org/10.1038/nbt0502-473

Fryxell KJ (1996): The coevolution of gene family trees. Trends Genet. 12, 364-369 https://doi.org/10.1016/S0168-9525(96)80020-5

Galarneau A, Primeau M, Trudeau LE, Michnick SW (2002): Beta-lactamase protein fragment complementation assays as in 
vivo and in vitro sensors of protein protein interactions. Nat. Biotechnol. 20, 619-622

https://doi.org/10.1038/nbt0602-619

Gally JA, Edelman GM (1964): Protein-Protein interactions among $\mathrm{L}$ polypeptide chains of Bence-Jones proteins and human gamma-globulins. J. Exp. Med. 119, 817-836 https://doi.org/10.1084/jem.119.5.817

Gasior E, Herrera F, Sadnik I, McLaughlin CS, Moldave K (1979): The preparation and characterization of a cell-free system from Saccharomyces cerevisiae that translates natural messenger ribonucleic acid. J. Biol. Chem. 254, 3965-3969 https://doi.org/10.1016/S0021-9258(18)50681-5

Gehl C, Waadt R, Kudla J, Mendel R-R, Hänsch R (2009): New GATEWAY vectors for high throughput analyses of proteinprotein interactions by bimolecular fluorescence complementation. Mol. Plant 2, 1051-1058 https://doi.org/10.1093/mp/ssp040

Ghosh I, Hamilton AD, Regan L (2000): Antiparallel leucine zipper-directed protein reassembly: application to the green fluorescent protein. J. Am. Chem. Soc. 122, 5658-5659 https://doi.org/10.1021/ja994421w

Giannone G, Hosy E, Levet F, Constals A, Schulze K, Sobolevsky AI, Rosconi MP, Gouaux E, Tampé R, Choquet D (2010): Dynamic superresolution imaging of endogenous proteins on living cells at ultra-high density. Biophys. J. 99, 1303-1310 https://doi.org/10.1016/j.bpj.2010.06.005

Gingras A-C, Gstaiger M, Raught B, Aebersold R (2007): Analysis of protein complexes using mass spectrometry. Nat. Rev. Mol. Cell Biol. 8, 645-654 https://doi.org/10.1038/nrm2208

Goh CS, Bogan AA, Joachimiak M, Walther D, Cohen FE (2000): Co-evolution of proteins with their interaction partners. J. Mol. Biol. 299, 283-293 https://doi.org/10.1006/jmbi.2000.3732

Gonzalez-Lozano MA, Koopmans F, Sullivan PF, Protze J, Krause G, Verhage M, Li KW, Liu F, Smit AB (2020): Stitching the synapse: Cross-linking mass spectrometry into resolving synaptic protein interactions. Sci. Adv. 6, eaax5783 https://doi.org/10.1126/sciadv.aax5783

Gonzalez MW, Kann MG (2012): Chapter 4: Protein interactions and disease. PLoS Comput. Biol. 8, e1002819 https://doi.org/10.1371/journal.pcbi.1002819

Green NM (1990): Avidin and streptavidin. Methods Enzymol. 184, 51-67 https://doi.org/10.1016/0076-6879(90)84259-J

Greenfield NJ (2004): Circular dichroism analysis for proteinprotein interactions. In: Methods Mol. Biol. (Ed. H Fu), pp. 55-78, Humana Press, Totowa, NJ, USA

Greenfield NJ, Fasman GD (1969): Computed circular dichroism spectra for the evaluation of protein conformation. Biochemistry 8, 4108-4116 https://doi.org/10.1021/bi00838a031

Gyuris J, Golemis E, Chertkov H, Brent R (1993): Cdi1, a human G1 and S phase protein phosphatase that associates with Cdk2. Cell 75, 791-803 https://doi.org/10.1016/0092-8674(93)90498-F

Ha T, Enderle T, Ogletree D, Chemla DS, Selvin PR, Weiss S (1996): Probing the interaction between two single molecules: fluores- cence resonance energy transfer between a single donor and a single acceptor. Proc. Natl. Acad. Sci. USA 93, 6264-6268 https://doi.org/10.1073/pnas.93.13.6264

Ha T (2001): Single-molecule fluorescence resonance energy transfer. Methods 25, 78-86 https://doi.org/10.1006/meth.2001.1217

Hail M, Lee M (1998): Use of affinity capillary electrophoresis for the study of protein and drug interactions. Analyst 123, 1455-1459 https://doi.org/10.1039/a800285a

Hall MD, Yasgar A, Peryea T, Braisted JC, Jadhav A, Simeonov A, Coussens NP (2016): Fluorescence polarization assays in highthroughput screening and drug discovery: a review. Methods Appl. Fluoresc. 4, 022001 https://doi.org/10.1088/2050-6120/4/2/022001

Han K-K, Richard C, Delacourte A (1984): Chemical cross-links of proteins by using bifunctional reagents. Int. J. Biochem. 16, 129-145 https://doi.org/10.1016/0020-711X(84)90064-8

Hanes J, Plückthun A (1997): In vitro selection and evolution of functional proteins by using ribosome display. Proc. Natl. Acad. Sci. USA 94, 4937-4942 https://doi.org/10.1073/pnas.94.10.4937

Hays LB, Chen YS, Hu JC (2000): Two-hybrid system for characterization of protein-protein interactions in E. coli. Biotechniques 29, 288-296 https://doi.org/10.2144/00292st04

Helms V (2008): Fluorescence resonance energy transfer. In: Principles of Computational Cell Biology. Wiley-VCH Verlag, Weinheim, Germany

Herzberg C, Weidinger LA, Dorrbecker B, Hubner S, Stulke J, Commichau FM (2007): SPINE: a method for the rapid detection and analysis of protein-protein interactions in vivo. Proteomics 7, 4032-4035 https://doi.org/10.1002/pmic.200700491

Hillenkamp F, Karas M, Beavis RC, Chait BT (1991): Matrix-assisted laser desorption/ionization mass spectrometry of biopolymers. Anal. Chem. 63, 1193A-1203A https://doi.org/10.1021/ac00024a716

Hirst M, Ho C, Sabourin L, Rudnicki M, Penn L, Sadowski I (2001): A two-hybrid system for transactivator bait proteins. Proc. Natl. Acad. Sci. USA 98, 8726-8731 https://doi.org/10.1073/pnas.141413598

Hoff B, Kuck U (2005): Use of bimolecular fluorescence complementation to demonstrate transcription factor interaction in nuclei of living cells from the filamentous fungus Acremonium chrysogenum. Curr. Genet. 47, 132-138

https://doi.org/10.1007/s00294-004-0546-0

Hohng S, Joo C, Ha T (2004): Single-molecule three-color FRET. Biophys. J. 87, 1328-1337

https://doi.org/10.1529/biophysj.104.043935

Hu CD, Chinenov Y, Kerppola TK (2002): Visualization of interactions among bZIP and Rel family proteins in living cells using bimolecular fluorescence complementation. Mol. Cell 9, 789-798 https://doi.org/10.1016/S1097-2765(02)00496-3

Huang KH, Fairclough RH, Cantor CR (1975): Singlet energy transfer studies of the arrangement of proteins in the $30 \mathrm{~S}$ Escherichia coli ribosome. J. Mol. Biol. 97, 443-470 
https://doi.org/10.1016/S0022-2836(75)80053-2

Hubsman M, Yudkovsky G, Aronheim A (2001): A novel approach for the identification of protein-protein interaction with integral membrane proteins. Nucleic Acids Res. 29, E18 https://doi.org/10.1093/nar/29.4.e18

Huynen M, Snel B, Lathe W, 3rd, Bork P (2000): Predicting protein function by genomic context: quantitative evaluation and qualitative inferences. Genome Res. 10, 1204-1210 https://doi.org/10.1101/gr.10.8.1204

Im J, Gopalakrishna K, Subramaniam S, Shrivastava M, Tumbde A, Jiang X, Dai J, Lee S, Pawar N, Li J et al. (2018) Pinot: realtime olap for 530 million users. In Proceedings of the 2018 International Conference on Management of Data, pp 583-594 https://doi.org/10.1145/3183713.3190661

Jarvius M, Paulsson J, Weibrecht I, Leuchowius K-J, Andersson A-C, Wählby C, Gullberg M, Botling J, Sjöblom T, Markova B (2007): In situ detection of phosphorylated platelet-derived growth factor receptor $\beta$ using a generalized proximity ligation method. Mol. Cell. Proteomics 6, 1500-1509 https://doi.org/10.1074/mcp.M700166-MCP200

Jerabek-Willemsen M, André T, Wanner R, Roth HM, Duhr S, Baaske P, Breitsprecher D (2014): MicroScale Thermophoresis: Interaction analysis and beyond. J. Mol. Struct. 1077, 101-113 https://doi.org/10.1016/j.molstruc.2014.03.009

Johnsson N, Varshavsky A (1994): Split ubiquitin as a sensor of protein interactions in vivo. Proc. Natl. Acad. Sci. USA 91, 10340-10344 https://doi.org/10.1073/pnas.91.22.10340

Joung JK, Ramm EI, Pabo CO (2000): A bacterial two-hybrid selection system for studying protein-DNA and protein-protein interactions. Proc. Natl. Acad. Sci. USA 97, 7382-7387 https://doi.org/10.1073/pnas.110149297

Kaiser R (1963): Use of the nuclear overhauser effect in the analysis of high-resolution nuclear magnetic resonance spectra. J. Chem. Phys. 39, 2435-2442 https://doi.org/10.1063/1.1734045

Karas M, Hillenkamp F (1988): Laser desorption ionization of proteins with molecular masses exceeding 10,000 daltons. Anal. Chem. 60, 2299-2301 https://doi.org/10.1021/ac00171a028

Karimova G, Pidoux J, Ullmann A, Ladant D (1998): A bacterial two-hybrid system based on a reconstituted signal transduction pathway. Proc. Natl. Acad. Sci. USA 95, 5752-5756 https://doi.org/10.1073/pnas.95.10.5752

Kenworthy AK (2001): Imaging protein-protein interactions using fluorescence resonance energy transfer microscopy. Methods 24, 289-296 https://doi.org/10.1006/meth.2001.1189

Kerppola TK (2006a): Complementary methods for studies of protein interactions in living cells. Nat. Methods 3, 969-971 https://doi.org/10.1038/nmeth1206-969

Kerppola TK (2006b): Design and implementation of bimolecular fluorescence complementation (BiFC) assays for the visualization of protein interactions in living cells. Nat. Protoc. 1, $1278-1286$ https://doi.org/10.1038/nprot.2006.201

Kessler SW (1975): Rapid isolation of antigens from cells with a staphylococcal protein A-antibody adsorbent: parameters of the interaction of antibody-antigen complexes with protein A. J. Immunol. 115, 1617-1624

Kettling U, Koltermann A, Schwille P, Eigen M (1998): Realtime enzyme kinetics monitored by dual-color fluorescence cross-correlation spectroscopy. Proc. Natl. Acad. Sci. USA 95, 1416-1420 https://doi.org/10.1073/pnas.95.4.1416

Kim J-Y, Chung HS (2020): Diverse transition paths of coupled binding and folding of intrinsically disordered protein proved by three-color single-molecule FRET. Biophys. J. 118, 491-492 https://doi.org/10.1016/j.bpj.2019.11.2722

Klockenbusch C, Kast J (2010): Optimization of formaldehyde cross-linking for protein interaction analysis of non-tagged integrin beta1. J. Biomed. Biotechnol. 2010, 927585 https://doi.org/10.1155/2010/927585

Kobe B, Guncar G, Buchholz R, Huber T, Maco B, Cowieson N, Martin JL, Marfori M, Forwood JK (2008): Crystallography and protein-protein interactions: biological interfaces and crystal contacts. Biochem. Soc. Trans. 36, 1438-1441 https://doi.org/10.1042/BST0361438

Kornacker MG, Remsburg B, Menzel R (1998): Gene activation by the AraC protein can be inhibited by DNA looping between AraC and a LexA repressor that interacts with AraC: possible applications as a two-hybrid system. Mol. Microbiol. 30, 615-624 https://doi.org/10.1046/j.1365-2958.1998.01096.x

Kornberg HL, Krebs HA (1957): Synthesis of cell constituents from C2units by a modified tricarboxylic acid cycle. Nature 179, 988-991 https://doi.org/10.1038/179988a0

Korycka-Wolowiec A, Wolowiec D, Kubiak-Mlonka A, Robak T (2019): Venetoclax in the treatment of chronic lymphocytic leukemia. Expert Opin. Drug Metab. Toxicol. 15, 353-366 https://doi.org/10.1080/17425255.2019.1606211

Krebs EG, Fischer EH (1962): Molecular properties and transformations of glycogen phosphorylase in animal tissues. Adv. Enzymol. Relat. Subj. Biochem. 24, 263-290 https://doi.org/10.1002/9780470124888.ch5

Krebs HA, Henseleit K (1932): Untersuchungen uber die Harnstoffbildung im Tierkörper. 210, 33-66 (in German) https://doi.org/10.1515/bchm2.1932.210.1-2.33

Krebs HA, Johnson WA (1937): The role of citric acid in intermediate metabolism in animal tissues. Enzymologia 4, 148-156

Kruppa GH, Schoeniger J, Young MM (2003): A top down approach to protein structural studies using chemical cross-linking and Fourier transform mass spectrometry. Rapid Commun. Mass Spectrom. 17, 155-162 https://doi.org/10.1002/rcm.885

Lakowicz JR (1999): Energy transfer. In: Principles of Fluorescence Spectroscopy (Ed. JR Lakowicz), pp 367-394, Springer Science+Bussines Media New York, New York, NY, USA https://doi.org/10.1007/978-1-4757-3061-6_13

Lam YA, Lawson TG, Velayutham M, Zweier JL, Pickart CM (2002): A proteasomal ATPase subunit recognizes the polyubiquitin degradation signal. Nature 416, 763-767 https://doi.org/10.1038/416763a

Langowski J (2008): Protein-protein interactions determined by fluorescence correlation spectroscopy. In: Fluorescent Proteins 
(Ed. KF Sullivan), pp 471-484, Elsevier Science Publishing, San Diego, CA, USA https://doi.org/10.1016/S0091-679X(08)85020-0

Laser H, Bongards C, Schüller J, Heck S, Johnsson N, Lehming $N$ (2000): A new screen for protein interactions reveals that the Saccharomyces cerevisiae high mobility group proteins Nhp6A/B are involved in the regulation of the GAL1 promoter. Proc. Natl. Acad. Sci. USA 97, 13732-13737 https://doi.org/10.1073/pnas.250400997

Latchman DS (1990): Eukaryotic transcription factors. Biochem. J. 270, 281 https://doi.org/10.1042/bj2700281

Leanna CA, Hannink M (1996): The reverse two-hybrid system: a genetic scheme for selection against specific protein/protein interactions. Nucleic Acids Res. 24, 3341-3347 https://doi.org/10.1093/nar/24.17.3341

Lee S-A, Chan C-h, Tsai C-H, Lai J-M, Wang F-S, Kao C-Y, Huang C-YF (2008): Ortholog-based protein-protein interaction prediction and its application to inter-species interactions. BMC Bioinformatics 9, 1-9 https://doi.org/10.1186/1471-2105-9-S12-S11

Licitra EJ, Liu JO (1996): A three-hybrid system for detecting small ligand-protein receptor interactions. Proc. Natl. Acad. Sci. USA 93, $12817-12821$ https://doi.org/10.1073/pnas.93.23.12817

Liedberg B, Nylander C, Lunström I (1983): Surface plasmon resonance for gas detection and biosensing. Sens. Actuators 4, 299-304 https://doi.org/10.1016/0250-6874(83)85036-7

Lin J-S, Lai E-M (2017): Protein-protein interactions: co-immunoprecipitation. In: Bacterial Protein Secretion Systems (Eds. L Journet, E Cascales), pp 211-219, Humana Press, New York, NY https://doi.org/10.1007/978-1-4939-7033-9_17

Lin S, Chen J-L, Huang L-S, Lin H-W (2005): Measurements of the forces in protein interactions with atomic force microscopy. Curr. Proteomics 2, 55-81 https://doi.org/10.2174/1570164053507754

Lodish H, Berk A, Kaiser CA, Krieger M, Bretscher A, Ploegh H, Martin KC, Yaffe M, Amon A (2021): Protein structure and function. In: Molecular Cell Biology, W. H. Freeman, New York

Lowe C, Dean P (1971): Affinity chromatography of enzymes on insolubilized cofactors. FEBS Lett. 14, 313-316 https://doi.org/10.1016/0014-5793(71)80288-0

Lu H, Zhou Q, He J, Jiang Z, Peng C, Tong R, Shi J (2020): Recent advances in the development of protein-protein interactions modulators: mechanisms and clinical trials. Signal Transduct. Target Ther. 5, 213 https://doi.org/10.1038/s41392-020-00315-3

Ludwig C (1856): Diffusion zwischen ungleich erwärmten Orten gleich zusammengesetzter Lösung. In: Aus der KK Hof-und Staatsdruckerei, in Commission bei W. Braumüller, Buchhändler des KK Hofes und der K. Akademie der Wissenschaften, pp 539-540, K.K. Hof- und Staatsdruckerei, Wien, Austria (in German)

Luo Y, Batalao A, Zhou H, Zhu L (1997): Mammalian two-hybrid system: a complementary approach to the yeast two-hybrid system. Biotechniques 22, 350-352 https://doi.org/10.2144/97222pf02
Maertens G, Vercammen J, Debyser Z, Engelborghs Y (2005): Measuring protein-protein interactions inside living cells using single color fluorescence correlation spectroscopy. Application to human immunodeficiency virus type 1 integrase and LEDGF/p75. FASEB J. 19, 1039-1041 https://doi.org/10.1096/fj.04-3373fje

Malonga H, Neault J, Arakawa H, Tajmir-Riahi H (2006): DNA interaction with human serum albumin studied by affinity capillary electrophoresis and FTIR spectroscopy. DNA Cell Biol. 25, 63-68 https://doi.org/10.1089/dna.2006.25.63

Manczak M, Reddy PH (2012): Abnormal interaction of VDAC1 with amyloid beta and phosphorylated tau causes mitochondrial dysfunction in Alzheimer's disease. Hum. Mol. Genet. 21, 5131-5146 https://doi.org/10.1093/hmg/dds360

Mao Y, Yu L, Yang R, Qu L-b, Harrington PdB (2015): A novel method for the study of molecular interaction by using microscale thermophoresis. Talanta 132, 894-901 https://doi.org/10.1016/j.talanta.2014.09.038

Markov DA, Swinney K, Bornhop DJ (2004): Label-free molecular interaction determinations with nanoscale interferometry. J. Am. Chem. Soc. 126, 16659-16664 https://doi.org/10.1021/ja047820m

Marsolier MC, Prioleau MN, Sentenac A (1997): A RNA polymerase III-based two-hybrid system to study RNA polymerase II transcriptional regulators. J. Mol. Biol. 268, 243-249 https://doi.org/10.1006/jmbi.1997.0979

Matzinger M, Mechtler K (2020): Cleavable cross-linkers and mass spectrometry for the ultimate task of profiling protein-protein interaction networks in vivo. J. Proteome Res. 20, 78-93 https://doi.org/10.1021/acs.jproteome.0c00583

Memišević V, Wallqvist A, Reifman J (2013): Reconstituting protein interaction networks using parameter-dependent domaindomain interactions. BMC Bioinformatics 14, 1-15 https://doi.org/10.1186/1471-2105-14-154

Mockli N, Deplazes A, Hassa PO, Zhang Z, Peter M, Hottiger MO, Stagljar I, Auerbach D (2007): Yeast split-ubiquitin-based cytosolic screening system to detect interactions between transcriptionally active proteins. Biotechniques 42, 725-730 https://doi.org/10.2144/000112455

Mon H, Sugahara R, Hong SM, Lee JM, Kamachi Y, Kawaguchi Y, Kusakabe T (2009): Analysis of protein interactions with two-hybrid system in cultured insect cells. Anal. Biochem. 392, 180-182 https://doi.org/10.1016/j.ab.2009.05.033

Morell M, Espargaro A, Aviles FX, Ventura S (2008): Study and selection of in vivo protein interactions by coupling bimolecular fluorescence complementation and flow cytometry. Nat. Protoc. 3, 22-33 https://doi.org/10.1038/nprot.2007.496

Morell M, Ventura S, Avilés FX (2009): Protein complementation assays: approaches for the in vivo analysis of protein interactions. FEBS Lett. 583, 1684-1691 https://doi.org/10.1016/j.febslet.2009.03.002

Neher RA, Neher E (2004): Applying spectral fingerprinting to the analysis of FRET images. Microsc. Res. Tech. 64, 185-195 https://doi.org/10.1002/jemt.20078 
Nguyen B, Tanious FA, Wilson WD (2007): Biosensor-surface plasmon resonance: quantitative analysis of small moleculenucleic acid interactions. Methods 42, 150-161 https://doi.org/10.1016/j.ymeth.2006.09.009

Nguyen HH, Park J, Kang S, Kim M (2015): Surface plasmon resonance: a versatile technique for biosensor applications. Sensors 15, 10481-10510 https://doi.org/10.3390/s150510481

Nickerson A, Huang T, Lin L-J, Nan X (2014): Photoactivated localization microscopy with bimolecular fluorescence complementation (BiFC-PALM) for nanoscale imaging of protein-protein interactions in cells. PLoS One 9, e100589 https://doi.org/10.1371/journal.pone.0100589

Noren KA, Noren CJ (2001): Construction of high-complexity combinatorial phage display peptide libraries. Methods 23, 169-178 https://doi.org/10.1006/meth.2000.1118

Nyfeler B, Michnick SW, Hauri H-P (2005): Capturing protein interactions in the secretory pathway of living cells. Proc. Natl. Acad. Sci. USA 102, 6350-6355

https://doi.org/10.1073/pnas.0501976102

O‘Connell MR, Gamsjaeger R, Mackay JP (2009): The structural analysis of protein-protein interactions by NMR spectroscopy. Proteomics 9, 5224-5232 https://doi.org/10.1002/pmic.200900303

O`Farrell PH (1975): High resolution two-dimensional electrophoresis of proteins. J. Biol. Chem. 250, 4007-4021 https://doi.org/10.1016/S0021-9258(19)41496-8

Ohashi K, Kiuchi T, Shoji K, Sampei K, Mizuno K (2012): Visualization of cofilin-actin and Ras-Raf interactions by bimolecular fluorescence complementation assays using a new pair of split Venus fragments. Biotechniques 52, 45-50 https://doi.org/10.2144/000113777

Ohh M, Park CW, Ivan M, Hoffman MA, Kim T-Y, Huang LE, Pavletich N, Chau V, Kaelin WG (2000): Ubiquitination of hypoxiainducible factor requires direct binding to the $\beta$-domain of the von Hippel-Lindau protein. Nat. Cell Biol. 2, 423-427 https://doi.org/10.1038/35017054

Olmsted J (1981): Affinity purification of antibodies from diazotized paper blots of heterogeneous protein samples. J. Biol. Chem. 256, 11955-11957 https://doi.org/10.1016/S0021-9258(18)43211-5

Oughtred R, Stark C, Breitkreutz BJ, Rust J, Boucher L, Chang C, Kolas N, O'Donnell L, Leung G, McAdam R, et al. (2019): The BioGRID interaction database: 2019 update. Nucleic Acids Res. 47, D529-D541 https://doi.org/10.1093/nar/gky1079

Paulmurugan R, Umezawa Y, Gambhir S (2002): Noninvasive imaging of protein-protein interactions in living subjects by using reporter protein complementation and reconstitution strategies. Proc. Natl. Acad. Sci. USA 99, 15608-15613 https://doi.org/10.1073/pnas.242594299

Pazos F, Valencia A (2001): Similarity of phylogenetic trees as indicator of protein-protein interaction. Protein Eng. 14, 609-614 https://doi.org/10.1093/protein/14.9.609

Pazos F, Valencia A (2002): In silico two-hybrid system for the selection of physically interacting protein pairs. Proteins 47, 219-227 https://doi.org/10.1002/prot.10074
Pelham HR, Jackson RJ (1976): An efficient mRNA-dependent translation system from reticulocyte lysates. Eur. J. Biochem. 67, 247-256 https://doi.org/10.1111/j.1432-1033.1976.tb10656.x

Pelletier JN, Campbell-Valois FX, Michnick SW (1998): Oligomerization domain-directed reassembly of active dihydrofolate reductase from rationally designed fragments. Proc. Natl. Acad. Sci. USA 95, 12141-12146 https://doi.org/10.1073/pnas.95.21.12141

Perera T, Gunasekara H, Hu YS (2020): Single-molecule interaction microscopy reveals antibody binding kinetics. BioRxiv https://doi.org/10.1101/2020.09.21.306605

Perrin F (1926): Polarisation de la lumière de fluorescence. Vie moyenne des molécules dans l'etat excité. Journal de Physique et le Radium 7, 390-401 (in French) https://doi.org/10.1051/jphysrad:01926007012039000

Pierce MM, Raman C, Nall BT (1999): Isothermal titration calorimetry of protein-protein interactions. Methods 19, 213-221 https://doi.org/10.1006/meth.1999.0852

Qureshi MH, Wong S-L (2002): Design, production, and characterization of a monomeric streptavidin and its application for affinity purification of biotinylated proteins. Protein Expression Purif. 25, 409-415 https://doi.org/10.1016/S1046-5928(02)00021-9

Ratner D (1974): The interaction bacterial and phage proteins with immobilized Escherichia coli RNA polymerase. J. Mol. Biol. 88, 373-383 https://doi.org/10.1016/0022-2836(74)90488-4

Reck M, Rodríguez-Abreu D, Robinson AG, Hui R, Csőszi T, Fülöp A, Gottfried M, Peled N, Tafreshi A, Cuffe S (2016): Pembrolizumab versus chemotherapy for PD-L1-positive non-small-cell lung cancer. N. Engl. J. Med. 375, 1823-1833 https://doi.org/10.1056/NEJMoa1606774

Redweik S, Cianciulli C, Hara M, Xu Y, Wätzig H (2013): Precise, fast and flexible determination of protein interactions by affinity capillary electrophoresis. Part 2: cations. Electrophoresis 34, 1812-1819 https://doi.org/10.1002/elps.201300050

Remy I, Michnick SW (2007): Application of protein-fragment complementation assays in cell biology. Biotechniques 42, $137-145$ https://doi.org/10.2144/000112396

Remy I, Michnick SW (1999): Clonal selection and in vivo quantitation of protein interactions with protein-fragment complementation assays. Proc. Natl. Acad. Sci. USA 96, 5394-5399 https://doi.org/10.1073/pnas.96.10.5394

Remy I, Michnick SW (2006): A highly sensitive protein-protein interaction assay based on Gaussia luciferase. Nat. Methods 3, 977-979 https://doi.org/10.1038/nmeth979

Remy I, Michnick SW (2004): Regulation of apoptosis by the Ft1 protein, a new modulator of protein kinase B/Akt. Mol. Cell. Biol. 24, 1493-1504 https://doi.org/10.1128/MCB.24.4.1493-1504.2004

Rich RL, Myszka DG (2000): Advances in surface plasmon resonance biosensor analysis. Curr. Opin. Biotechnol. 11, 54-61 https://doi.org/10.1016/S0958-1669(99)00054-3 
Roberts BE, Paterson BM (1973): Efficient translation of tobacco mosaic virus RNA and rabbit globin 9S RNA in a cell-free system from commercial wheat germ. Proc. Natl. Acad. Sci. USA 70, 2330-2334

https://doi.org/10.1073/pnas.70.8.2330

Roberts RW, Szostak JW (1997): RNA-peptide fusions for the in vitro selection of peptides and proteins. Proc. Natl. Acad. Sci. USA 94, 12297-12302 https://doi.org/10.1073/pnas.94.23.12297

Rossi F, Charlton CA, Blau HM (1997): Monitoring proteinprotein interactions in intact eukaryotic cells by betagalactosidase complementation. Proc. Natl. Acad. Sci. USA 94, $8405-8410$

https://doi.org/10.1073/pnas.94.16.8405

Sadowski I, Ma J, Triezenberg S, Ptashne M (1988): GAL4-VP16 is an unusually potent transcriptional activator. Nature 335, 563-564 https://doi.org/10.1038/335563a0

Sanger F, Air GM, Barrell BG, Brown NL, Coulson AR, Fiddes CA, Hutchison CA, Slocombe PM, Smith M (1977): Nucleotide sequence of bacteriophage phi X174 DNA. Nature 265, 687-695

https://doi.org/10.1038/265687a0

Sapsford KE, Berti L, Medintz IL (2006): Materials for fluorescence resonance energy transfer analysis: beyond traditional donor-acceptor combinations. Angew. Chem. Int. Ed. Engl. 45, 4562-4589 https://doi.org/10.1002/anie.200503873

Selkoe DJ, Abraham C, Ihara Y (1982): Brain transglutaminase: in vitro crosslinking of human neurofilament proteins into insoluble polymers. Proc. Natl. Acad. Sci. USA 79, 6070-6074 https://doi.org/10.1073/pnas.79.19.6070

SenGupta DJ, Zhang B, Kraemer B, Pochart P, Fields S, Wickens M (1996): A three-hybrid system to detect RNA-protein interactions in vivo. Proc. Natl. Acad. Sci. USA 93, 8496-8501 https://doi.org/10.1073/pnas.93.16.8496

Serebriiskii I, Khazak V, Golemis EA (1999): A two-hybrid dual bait system to discriminate specificity of protein interactions. J. Biol. Chem. 274, 17080-17087 https://doi.org/10.1074/jbc.274.24.17080

Serebryannyy LA, Misteli T (2019): HiPLA: High-throughput imaging proximity ligation assay. Methods 157, 80-87 https://doi.org/10.1016/j.ymeth.2018.11.004

Sharonov A, Hochstrasser RM (2006): Wide-field subdiffraction imaging by accumulated binding of diffusing probes. Proc. Natl. Acad. Sci. USA 103, 18911-18916 https://doi.org/10.1073/pnas.0609643104

Shatnawi M (2015): Review of recent protein-protein interaction techniques. In: Emerging Trends in Computational Biology, Bioinformatics, and Systems Biology (Ed.Q-N Tran, H Arabnia), pp 99-121, Morgan Kaufmann Publishers, San Francisco, CA, USA https://doi.org/10.1016/B978-0-12-802508-6.00006-5

Schmitt-Ulms G, Hansen K, Liu J, Cowdrey C, Yang J, DeArmond SJ, Cohen FE, Prusiner SB, Baldwin MA (2004): Time-controlled transcardiac perfusion cross-linking for the study of protein interactions in complex tissues. Nat. Biotechnol. 22, 724-731 https://doi.org/10.1038/nbt969
Schwille P, Meyer-Almes F-J, Rigler R (1997): Dual-color fluorescence cross-correlation spectroscopy for multicomponent diffusional analysis in solution. Biophys. J. 72, 1878-1886 https://doi.org/10.1016/S0006-3495(97)78833-7

Sinsky J, Majerova P, Kovac A, Kotlyar M, Jurisica I, Hanes J (2020): Physiological tau interactome in brain and its link to tauopathies. J. Proteome Res. 19, 2429-2442 https://doi.org/10.1021/acs.jproteome.0c00137

Sinz A (2003): Chemical cross-linking and mass spectrometry for mapping three-dimensional structures of proteins and protein complexes. J. Mass Spectrom. 38, 1225-1237 https://doi.org/10.1002/jms.559

Smith GP (1985): Filamentous fusion phage: novel expression vectors that display cloned antigens on the virion surface. Science 228, 1315-1317 https://doi.org/10.1126/science.4001944

Socinski MA, Jotte RM, Cappuzzo F, Orlandi F, Stroyakovskiy D, Nogami N, Rodríguez-Abreu D, Moro-Sibilot D, Thomas CA, Barlesi F (2018): Atezolizumab for first-line treatment of metastatic nonsquamous NSCLC. N. Engl. J. Med. 378, 2288-2301 https://doi.org/10.1056/NEJMoa1716948

Soderberg O, Gullberg M, Jarvius M, Ridderstrale K, Leuchowius KJ, Jarvius J, Wester K, Hydbring P, Bahram F, Larsson LG, Landegren U (2006): Direct observation of individual endogenous protein complexes in situ by proximity ligation. Nat. Methods 3, 995-1000 https://doi.org/10.1038/nmeth947

Song Y, Madahar V, Liao J (2011): Development of FRET assay into quantitative and high-throughput screening technology platforms for protein-protein interactions. Ann. Biomed. Eng. 39, 1224-1234 https://doi.org/10.1007/s10439-010-0225-x

Spotts JM, Dolmetsch RE, Greenberg ME (2002): Time-lapse imaging of a dynamic phosphorylation-dependent protein-protein interaction in mammalian cells. Proc. Natl. Acad. Sci. USA 99, 15142-15147 https://doi.org/10.1073/pnas.232565699

Stagljar I, Korostensky C, Johnsson N, te Heesen S (1998): A genetic system based on split-ubiquitin for the analysis of interactions between membrane proteins in vivo. Proc. Natl. Acad. Sci. USA 95, 5187-5192 https://doi.org/10.1073/pnas.95.9.5187

Stark C, Breitkreutz B-J, Reguly T, Boucher L, Breitkreutz A, Tyers M (2006): BioGRID: a general repository for interaction datasets. Nucleic Acids Res. 34, D535-D539 https://doi.org/10.1093/nar/gkj109

Steinkellner T, Montgomery TR, Hofmaier T, Kudlacek O, Yang J-W, Rickhag M, Jung G, Lubec G, Gether U, Freissmuth M (2015): Amphetamine action at the cocaine-and antidepressantsensitive serotonin transporter is modulated by aCaMKII. J. Neurosci. 35, 8258-8271

https://doi.org/10.1523/JNEUROSCI.4034-14.2015

Stepanenko OV, Stepanenko OV, Shcherbakova DM, Kuznetsova IM, Turoverov KK, Verkhusha VV (2011): Modern fluorescent proteins: from chromophore formation to novel intracellular applications. BioTechniques 51, 313-318 https://doi.org/10.2144/000113765 
Stolpe T, Susslin C, Marrocco K, Nick P, Kretsch T, Kircher S (2005): In planta analysis of protein-protein interactions related to light signaling by bimolecular fluorescence complementation. Protoplasma 226, 137-146 https://doi.org/10.1007/s00709-005-0122-6

Stryer L (1978): Fluorescence energy transfer as a spectroscopic ruler. Annu. Rev. Biochem. 47, 819-846 https://doi.org/10.1146/annurev.bi.47.070178.004131

Stryer L, Haugland RP (1967): Energy transfer: a spectroscopic ruler. Proc. Natl. Acad. Sci. USA 58, 719-726 https://doi.org/10.1073/pnas.58.2.719

Stynen B, Van Dijck P, Tournu H (2010): A CUG codon adapted two-hybrid system for the pathogenic fungus Candida albicans. Nucleic Acids Res. 38, e184 https://doi.org/10.1093/nar/gkq725

Su G, Morris JH, Demchak B, Bader GD (2014): Biological network exploration with Cytoscape 3. Curr. Protoc. Bioinformatics 47, 1-24 https://doi.org/10.1002/0471250953.bi0813s47

Suchanek M, Radzikowska A, Thiele C (2005): Photo-leucine and photo-methionine allow identification of protein-protein interactions in living cells. Nat. Methods 2, 261-267 https://doi.org/10.1038/nmeth752

Sun Y, Wallrabe H, Seo SA, Periasamy A (2011): FRET microscopy in 2010: the legacy of Theodor Forster on the 100th anniversary of his birth. Chemphyschem 12, 462-474 https://doi.org/10.1002/cphc.201000664

Sundell GN, Ivarsson Y (2014): Interaction analysis through proteomic phage display. Biomed Res. Int. 2014, 176172 https://doi.org/10.1155/2014/176172

Swann MJ, Peel LL, Carrington S, Freeman NJ (2004): Dualpolarization interferometry: an analytical technique to measure changes in protein structure in real time, to determine the stoichiometry of binding events, and to differentiate between specific and nonspecific interactions. Anal. Biochem. 329, 190-198 https://doi.org/10.1016/j.ab.2004.02.019

Swinney K, Markov D, Bornhop DJ (2000): Chip-scale universal detection based on backscatter interferometry. Anal. Chem. 72, 2690-2695 https://doi.org/10.1021/ac000261r

Szklarczyk D, Gable AL, Lyon D, Junge A, Wyder S, HuertaCepas J, Simonovic M, Doncheva NT, Morris JH, Bork P (2019): STRING v11: protein-protein association networks with increased coverage, supporting functional discovery in genome-wide experimental datasets. Nucleic Acids Res. 47, D607-D613 https://doi.org/10.1093/nar/gky1131

Tafelmeyer P, Johnsson N, Johnsson K (2004): Transforming a (beta/ alpha)8--barrel enzyme into a split-protein sensor through directed evolution. Chem. Biol. 11, 681-689 https://doi.org/10.1016/j.chembiol.2004.02.026

Tang X, Bruce JE (2009): Chemical cross-linking for protein-protein interaction studies. Methods Mol. Biol. 492, 283-293 https://doi.org/10.1007/978-1-59745-493-3_17

Truong K, Ikura M (2001): The use of FRET imaging microscopy to detect protein-protein interactions and protein conformational changes in vivo. Curr. Opin. Struct. Biol. 11, 573-578 https://doi.org/10.1016/S0959-440X(00)00249-9
Tsoka S, Ouzounis CA (2000): Prediction of protein interactions: metabolic enzymes are frequently involved in gene fusion. Nat. Genet. 26, 141-142 https://doi.org/10.1038/79847

Tuite MF, Plesset J, Moldave K, McLaughlin C (1980): Faithful and efficient translation of homologous and heterologous mRNAs in an mRNA-dependent cell-free system from Saccharomyces cerevisiae. J. Biol. Chem. 255, 8761-8766 https://doi.org/10.1016/S0021-9258(18)43566-1

Urech DM, Lichtlen P, Barberis A (2003): Cell growth selection system to detect extracellular and transmembrane protein interactions. Biochim. Biophys. Acta 1622, 117-127 https://doi.org/10.1016/S0304-4165(03)00133-8

Van Craenenbroeck E, Engelborghs Y (1999): Quantitative characterization of the binding of fluorescently labeled colchicine to tubulin in vitro using fluorescence correlation spectroscopy. Biochemistry 38, 5082-5088 https://doi.org/10.1021/bi9821925

Van Criekinge W, Beyaert R (1999): Yeast two-hybrid: state of the art. Biol. Proced. Online 2, 1-38 https://doi.org/10.1251/bpo16

Vasilescu J, Guo X, Kast J (2004): Identification of protein-protein interactions using in vivo cross-linking and mass spectrometry. Proteomics 4, 3845-3854 https://doi.org/10.1002/pmic.200400856

Vidal M, Brachmann RK, Fattaey A, Harlow E, Boeke JD (1996): Reverse two-hybrid and one-hybrid systems to detect dissociation of protein-protein and DNA-protein interactions. Proc. Natl. Acad. Sci. USA 93, 10315-10320 https://doi.org/10.1073/pnas.93.19.10315

Virtanen R (1974): Zone Electrophoresis in Narrow-bore tube employing Potentiometric detection. A theoretical and experimental study. Finnish Acad. of Techn. Sciences

von Behring E, Kitasato S (1991): [The mechanism of diphtheria immunity and tetanus immunity in animals. 1890]. Mol. Immunol. 28, 1317, 1319-1320 (in German)

Weber G (1952): Polarization of the fluorescence of macromolecules. 1. Theory and experimental method. Biochem. J. 51, 145-155 https://doi.org/10.1042/bj0510145

Weber G (1960): Fluorescence-polarization spectrum and electronic-energy transfer in proteins. Biochem. J. 75, 345 https://doi.org/10.1042/bj0750345

Wehr MC, Laage R, Bolz U, Fischer TM, Grunewald S, Scheek S, Bach A, Nave KA, Rossner MJ (2006): Monitoring regulated protein-protein interactions using split TEV. Nat. Methods 3, 985-993 https://doi.org/10.1038/nmeth967

Wiseman T, Williston S, Brandts JF, Lin L-N (1989): Rapid measurement of binding constants and heats of binding using a new titration calorimeter. Anal. Biochem. 179, 131-137 https://doi.org/10.1016/0003-2697(89)90213-3

Wojcik J, Schächter V (2001): Protein-protein interaction map inference using interacting domain profile pairs. Bioinformatics 17, S296-S305

https://doi.org/10.1093/bioinformatics/17.suppl_1.S296

Woody RW (1995): [4] Circular dichroism. In: Methods Enzymol. (Ed. K Sauer), pp 34-71, Academic Press, New York, USA 
https://doi.org/10.1016/0076-6879(95)46006-3

Wouters FS, Bastiaens PI, Wirtz KW, Jovin TM (1998): FRET microscopy demonstrates molecular association of non-specific lipid transfer protein (nsL-TP) with fatty acid oxidation enzymes in peroxisomes. EMBO J. 17, 7179-7189 https://doi.org/10.1093/emboj/17.24.7179

Wu J, Vallenius T, Ovaska K, Westermarck J, Makela TP, Hautaniemi S (2009): Integrated network analysis platform for proteinprotein interactions. Nat. Methods 6, 75-77 https://doi.org/10.1038/nmeth.1282

Xenarios I, Salwinski L, Duan XJ, Higney P, Kim S-M, Eisenberg D (2002): DIP, the Database of Interacting Proteins: a research tool for studying cellular networks of protein interactions. Nucleic Acids Res. 30, 303-305 https://doi.org/10.1093/nar/30.1.303

Xing S, Wallmeroth N, Berendzen KW, Grefen C (2016): Techniques for the analysis of protein-protein interactions in vivo. Plant Physiol. 171, 727-758 https://doi.org/10.1104/pp.16.00470

Xu Y, Piston DW, Johnson CH (1999): A bioluminescence resonance energy transfer (BRET) system: application to interacting circadian clock proteins. Proc. Natl. Acad. Sci. USA 96, 151-156 https://doi.org/10.1073/pnas.96.1.151

Yaciuk P (2007): Co-immunoprecipitation of protein complexes. In: Adenovirus Methods and Protocols (Ed. Wold WSM, Tollefson AE), pp 103-111, Humana Press, Totowa, New Jersey, USA https://doi.org/10.1007/978-1-59745-277-9_8

Yeow EK, Clayton AH (2007): Enumeration of oligomerization states of membrane proteins in living cells by homo-FRET spectroscopy and microscopy: theory and application. Biophys. J. 92, 3098-3104 https://doi.org/10.1529/biophysj.106.099424

Young MM, Tang N, Hempel JC, Oshiro CM, Taylor EW, Kuntz ID, Gibson BW, Dollinger G (2000): High throughput protein fold identification by using experimental constraints derived from intramolecular cross-links and mass spectrometry. Proc. Natl. Acad. Sci. USA 97, 5802-5806 https://doi.org/10.1073/pnas.090099097

Zamyatnin AA, Jr., Solovyev AG, Bozhkov PV, Valkonen JP, Morozov SY, Savenkov EI (2006): Assessment of the integral membrane protein topology in living cells. Plant J. 46, 145-154 https://doi.org/10.1111/j.1365-313X.2006.02674.x

Zhang J, Lautar S (1996): A yeast three-hybrid method to clone ternary protein complex components. Anal. Biochem. 242, 68-72 https://doi.org/10.1006/abio.1996.0429

Zhang QC, Petrey D, Garzón JI, Deng L, Honig B (2012): PrePPI: a structure-informed database of protein-protein interactions. Nucleic Acids Res. 41, D828-D833 https://doi.org/10.1093/nar/gks196

Zhao X, Xu JR (2007): A highly conserved MAPK-docking site in Mst7 is essential for Pmk1 activation in Magnaporthe grisea. Mol. Microbiol. 63, 881-894 https://doi.org/10.1111/j.1365-2958.2006.05548.x

Zuiderweg ER (2002): Mapping protein-protein interactions in solution by NMR spectroscopy. Biochemistry 41, 1-7 https://doi.org/10.1021/bi011870b

Received: April 30, 2021

Final version accepted: September 3, 2021 